OECD Economics Department Working Papers No. 1281

\title{
Monetary Policy and Inequality
}

\section{Kukasz Rawdanowicz, \\ Kei-Ichiro Inaba}




\section{Unclassified}

ECO/WKP(2016)5

Organisation de Coopération et de Développement Économiques

Organisation for Economic Co-operation and Development

23-Feb-2016

ECONOMICS DEPARTMENT

English - Or. English

MONETARY POLICY AND INEQUALITY

ECONOMICS DEPARTMENT WORKING PAPERS No. 1281

By Rory O'Farrell, Lukasz Rawdanowicz and Kei-Ichiro Inaba

OECD Working Papers should not be reported as representing the official views of the OECD or of its member countries. The opinions expressed and arguments employed are those of the author(s).

Authorised for publication by Jean-Luc Schneider, Deputy Director, Policy Studies Branch, Economics Department.

All Economics Department Working Papers are available at www.oecd.org/eco/workingpapers

JT03390505

Complete document available on OLIS in its original format

This document and any map included herein are without prejudice to the status of or sovereignty over any territory, to the delimitation of international frontiers and boundaries and to the name of any territory, city or area. 
OECD Working Papers should not be reported as representing the official views of the OECD or of its member countries. The opinions expressed and arguments employed are those of the author(s).

Working Papers describe preliminary results or research in progress by the author(s) and are published to stimulate discussion on a broad range of issues on which the OECD works.

Comments on Working Papers are welcomed, and may be sent to the Economics Department, OECD, 2 rue André-Pascal, 75775 Paris Cedex 16, France, or by e-mail to eco.contact@oecd.org.

All Economics Department Working Papers are available at www.oecd.org/eco/workingpapers.

\section{(C) OECD (2016)}

You can copy, download or print OECD content for your own use, and you can include excerpts from OECD publications, databases and multimedia products in your own documents, presentations, blogs, websites and teaching materials, provided that suitable acknowledgment of OECD as source and copyright owner is given. All requests for commercial use and translation rights should be submitted to rights@oecd.org 


\section{ABSTRACT/RÉSUMÉ}

\section{Monetary Policy and Inequality}

This paper analyses two-way interactions between monetary policy and inequality in selected advanced economies. In the context of a highly accommodative monetary stance over recent years, the analysis focuses on the effects of monetary policy on inequality over the business cycle via its impacts on returns on assets, the cost of debt servicing and asset prices. While monetary policy easing has a priori ambiguous effects on income and net wealth inequality, in practice these effects are estimated to be small. Cross-country differences in the size and distribution of income and net wealth explain contrasting effects. A house price increase generally reduces net wealth inequality, while the opposite is true for increases in equity and bond prices. Higher inequality can reduce the effectiveness of monetary policy stimulus in boosting private consumption, but such effects are estimated to be small. Cross-country differences in the size and composition of household financial assets rather than in their distribution are more relevant for differences in the effectiveness of monetary policy, especially via the wealth channel.

JEL classification codes: D31, D63, E21, E3, E5.

Key words: income inequality, net wealth inequality, monetary policy, consumption wealth effects.

$* * * * * * * * * * * * * * * * * * * * *$

\section{Politique monétaire et inégalités}

Le présent article a pour objet d'analyser les interactions réciproques entre la politique monétaire et les inégalités dans certaines économies avancées. Dans le contexte d'une politique monétaire très accommodante au cours des dernières années, l'analyse se concentre sur les effets que la politique monétaire, par son impact sur les rendements des actifs, le coût du service de la dette et les prix des actifs, a eu sur les inégalités au cours du cycle conjoncturel. Si la politique monétaire accommodante a des effets a priori ambigus sur les inégalités de revenu et de richesse nette, dans la pratique, on estime que ces effets sont plutôt faibles. Les différences entre pays concernant le montant et la distribution des revenus et de richesse nette expliquent les divergences dans les effets. Une augmentation des prix des logements a généralement pour conséquence de réduire les inégalités de richesse nette, alors que l'augmentation des cours des actions et des obligations produit un effet contraire. Des inégalités élevées peuvent réduire l'efficacité des mesures de relance monétaire pour stimuler la consommation privée, mais on estime que ces effets sont faibles. Les différences entre pays en termes d'ampleur et de composition des actifs financiers des ménages sont plus pertinentes que les différences relevées dans leur distribution lorsqu'il s'agit d'apprécier l'efficacité de la politique monétaire, particulièrement via le canal de la richesse.

Classification JEL : D31, D63, E21, E3, E5.

Mots clefs : inégalités de revenu, inégalités de richesse nette, politique monétaire, effets de la richesse sur la consommation. 


\section{TABLE OF CONTENTS}

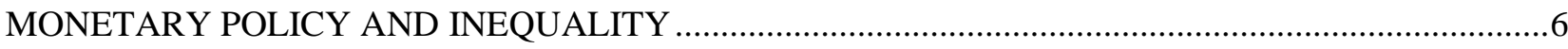

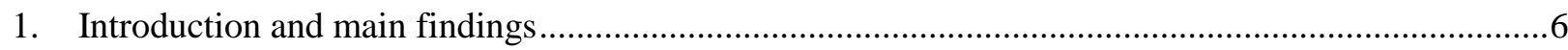

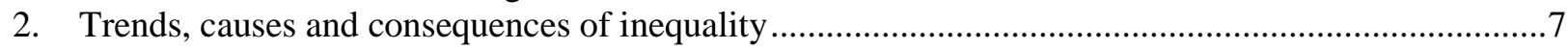

3. Effects of monetary policy on inequality via interest rates and asset prices...................................12

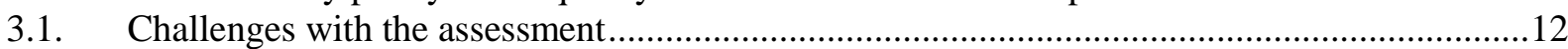

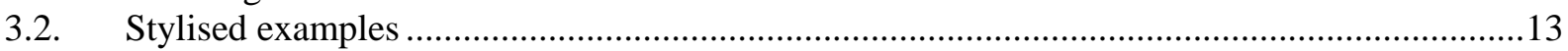

4. Income and wealth inequality and monetary policy transmission ..............................................21

4.1. Income inequality affects monetary policy transmission to consumption only marginally ......21

4.2. The extent of wealth inequality does not affect the effectiveness of monetary policy either....22

4.3. Inequality is unlikely to significantly reduce monetary policy effectiveness by

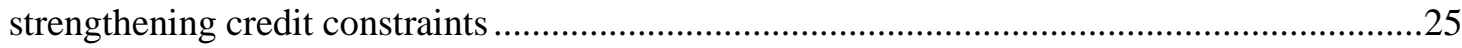

4.4. Cross-country differences in monetary policy effectiveness due to different size,

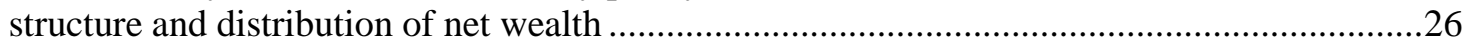

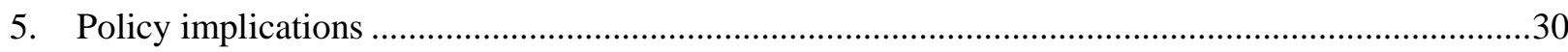

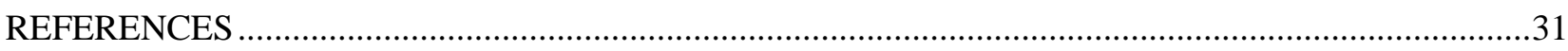

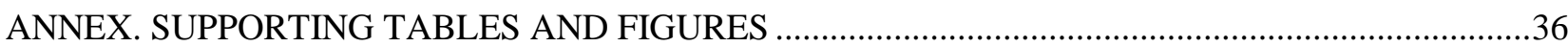

\section{Tables}

Table 1. Stylised effects of a 4-percentage point interest rate cut on income inequality.....................15

Table 2. Stylised effects of a $10 \%$ increase in asset prices on wealth inequality ..............................20

Table 3. Stylised net wealth distribution effects with a different skewness of assets ........................20

Table 4. Stylised net wealth distribution effects with different asset skewness, portfolios

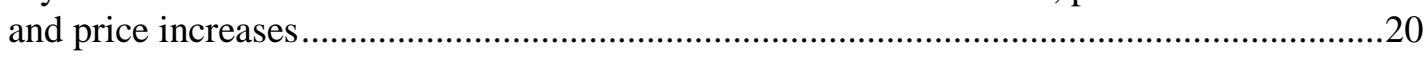

Table 5. The impact of the size, composition and distribution of net wealth

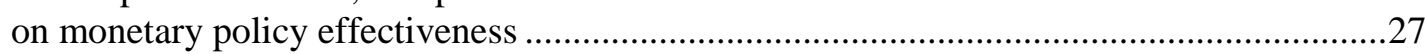

Table 6. Large cross-country variation in shares of variable-rate mortgages ....................................27

Table A1. Households at the bottom of the net wealth distribution are more leveraged

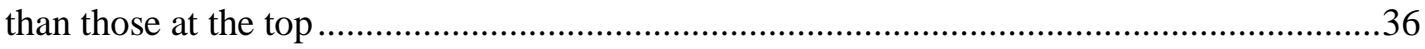

Table A2. Marginal propensity to consume by income deciles.............................................................36

Table A3. Marginal propensity to consume by wealth deciles...........................................................37 


\section{Figures}

Figure 1. Income and wealth inequality have increased in recent decades .......................................8

Figure 2. Income and wealth inequality vary across OECD countries.............................................

Figure 3. Determinants of interest rate cut effects on the income distribution .................................14

Figure 4. Determinants of interest rate cut effects on the income distribution with dividends...........18

Figure 5. Mean housing wealth is lower for younger households..............................................25

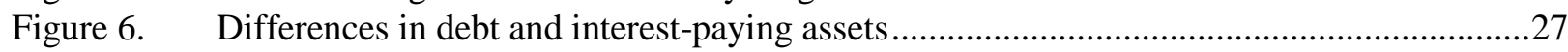

Figure 7. The size and composition of assets vary across advanced countries ................................28

Figure 8. The cumulative distribution of responsive assets does not vary much among

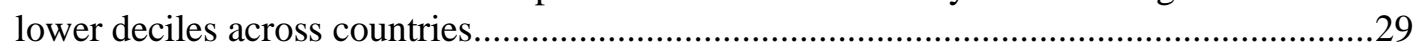

Figure A1. Income sources differ across the income distribution.......................................................37

\section{Boxes}

Box 1. Income and wealth inequality during the Great Recession ..............................................

Box 2. Does monetary policy affect income inequality via returns on net wealth? ........................16

Box 3. Aggregate wealth effects on consumption..................................................................23

Box 4. How does inequality affect the transmission of monetary policy through the wealth channel? 


\title{
MONETARY POLICY AND INEQUALITY
}

\author{
Rory O'Farrell, Łukasz Rawdanowicz and Kei-Ichiro Inaba ${ }^{1}$
}

\section{Introduction and main findings}

Rising inequality of income and wealth in advanced economies, its drivers and its consequences have attracted considerable attention from researchers and policy makers. Central bankers have also become interested in inequality (Coeuré, 2012; Bullard, 2014; Yellen, 2014; Panetta, 2015) as recent sizeable conventional monetary stimulus and quantitative easing have been perceived to increase inequality given their apparent strong effects on asset prices. Monetary policy has the potential to affect income and wealth inequality. At the same time, inequality can influence the effectiveness of monetary policy, as less wealthy and lower-income households, with a higher marginal propensity to consume, are less likely to hold assets and more likely to be credit constrained. This paper reviews the interactions between inequality and monetary policy in the light of the growing empirical and theoretical literature. The main focus is on the impact of monetary policy on income and wealth via changes in returns on assets, debt interest payments and asset prices, rather than via its impact on employment and inflation.

The paper demonstrates that monetary policy effects on income and net wealth inequality via financial channels are complex and ambiguous a priori, and in practice they tend to be small. Cross-country differences in the size and distribution of income and net wealth components explain contrasting effects. A house price increase generally reduces net wealth inequality, while the opposite is true for increases in equity and bond prices. Larger effects could be expected when effects via employment are taken into account, but such effects are difficult to incorporate in the analytical framework adopted in this paper. Asymmetric monetary policy over the business cycle may affect inequality over a longer period but this is not investigated. Higher inequality does not seem to significantly affect the effectiveness of monetary policy in boosting private consumption via wealth effects. Cross-country differences in the size and composition of household financial assets rather than in their distribution are more relevant for differences in the effectiveness of monetary policy, especially via the wealth channel.

The rest of the paper is organised as follows. Section 2 summarises trends, causes and consequences of rising income and wealth inequality over recent decades. Section 3 outlines challenges with assessing monetary policy effects on inequality and provides stylised and country-specific simulations on how changes in interest rates and asset prices affect income and net wealth inequality. Section 4 investigates the impact of inequality on the effectiveness of monetary policy in boosting household consumption. Finally, Section 5 provides policy implications.

1. The authors are members of the Macroeconomic Policy Division of the Economics Department. They are indebted to Jérôme Brezillon and Ane Kathrine Christensen for statistical assistance, and to Isabelle Fakih for help in the final document preparation. They are grateful to Sveinbjörn Blöndal, Orsetta Causa, Boris Cournède, Oliver Denk, Mikkel Hermansen, Catherine L. Mann, Jonathan Millar and Jean-Luc Schneider for their useful comments. US data were downloaded using the $R$ script of Anthony Damico (Kaiser Family Foundation). 


\section{Trends, causes and consequences of inequality}

Since the 1970s, both wealth and income inequality have steadily increased in most OECD countries (OECD, 2015; Figure 1). Initial levels of inequality and the magnitude of their increase have varied across countries, with greater inequality and a larger rise in the United States than in Europe. The recent financial crisis has exacerbated income and wealth inequality in many advanced economies (Piketty, 2014; OECD, 2015; Box 1). The resulting levels of wealth and income inequality differ considerably across the OECD (Figure 2).

A number of features have contributed to rising income and wealth inequality.

- Regarding income inequality, skill-biased technical change (Acemoglu, 2002), increased global trade (Feenstra and Hanson, 2004), de-unionisation (Card, 2001; Jaumotte and Osorio Buitron, 2015), and population ageing (Heathcote et al., 2010; Karahan and Ozkan, 2013) have been identified as causal factors. The increase in post-tax income inequality also reflects the decline in top marginal personal income tax rates. Studies investigating drivers of rising income inequality do not identify monetary policy as an important factor (Coibion et al., 2012).

- As for wealth inequality, strong capital gains (especially for equities) and, to a lesser extent, higher income inequality, falling relative ability to save for most households, and inheritances, have contributed to its increase (Smith, 2004; Saez and Zucman, 2014).

Income and wealth inequality could be also affected by inflation. However, theoretical channels and empirical evidence are not clear about the direction of the effects, and they tend to suggest that the effects are negligible for low-inflation countries. High inflation may increase income inequality but deflation is unlikely to have the opposite effect given downward nominal rigidities. ${ }^{2}$ Empirical evidence about the link between inflation and income inequality is inconclusive, but, at low inflation levels, inflation seems to have no impact on inequality. ${ }^{3}$ Inflation can also redistribute wealth, as lower income households hold a higher share of their financial assets in cash (Mulligan and Sala-i-Martin, 2000). This implies that high inflation may increase wealth inequality. In contrast, inflation has the potential to diminish wealth inequality by transferring wealth from lenders to borrowers due to reduced real value of nominal assets and liabilities (Nakajima, 2015). Doepke and Schneider (2006) show that positive inflation surprises benefit young, middle-class households with fixed-rate mortgage debt, but hurt rich and old households. ${ }^{4}$

2. High inflation can reduce disposable income of low-income households more than for high-income households because wage and social security benefits, accounting for a higher share of total income of low-income households, are less indexed to inflation than non-wage income for high-income households. In addition, inflation could affect low-income households more, if inflation is higher for basic goods and services than for remaining goods and services.

3. Country-specific studies for developed countries surveyed by Parker (1999) and Galli and van der Hoeven (2001) find no persistently negative or positive relationship between inflation and income inequality. However, cross-country studies find that high inflation is associated with higher income equality in the longer term (Bulír and Gule, 1995; Al-Marhubi, 1997; Romer and Romer, 1999; Albanesi, 2007). Bulír (2001) demonstrates that the negative relationship is present in high-inflation countries, especially during hyperinflation, but not in countries with low inflation.

4. Five per cent annual inflation would cost rich elderly households roughly between 5\% and 15\% of GDP, with two-thirds of the loss being suffered by households in the top decile. Three-quarters of the gains would go to the middle class under 45 years old. However, with a fully unanticipated shock, equity holders, who tend to be in the upper net wealth deciles, would always gain. 
Figure 1. Income and wealth inequality have increased in recent decades

\section{A. The share of the top decile in total wealth}

$\%$

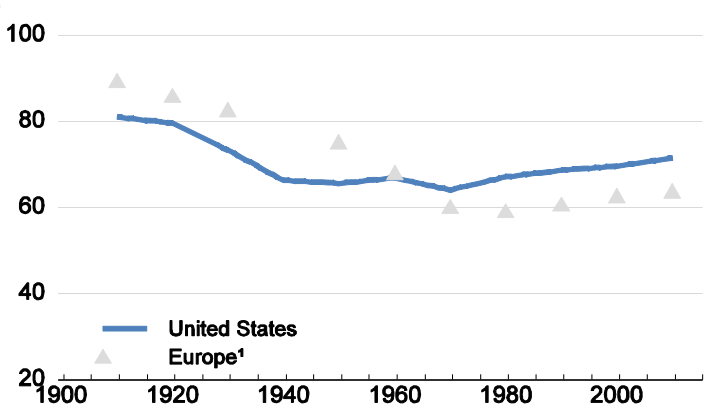

B. The share of the top decile in total income ${ }^{2}$

$\%$

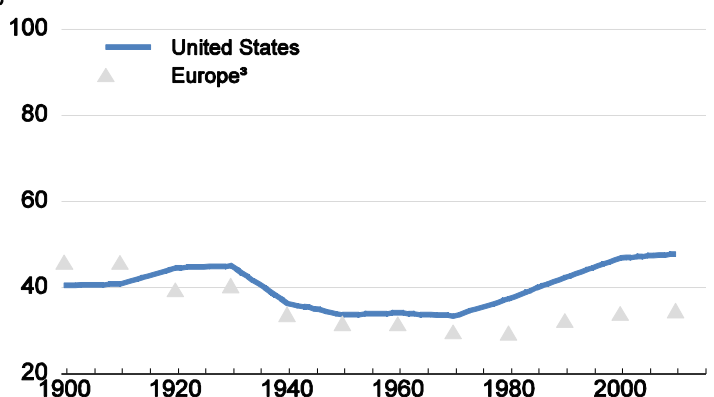

1. An arithmetic average of the wealth shares in France, Sweden and the United Kingdom.

2. Total income is calculated from income tax returns. It is defined as market income (before tax) plus social transfers that are based on contributory schemes, but excludes "pure transfers" such as minimum social payments.

3. An arithmetic average of the income shares in France, Germany, Sweden and the United Kingdom.

Source: Piketty (2014), Capital in the Twenty-First Century.

Figure 2. Income and wealth inequality vary across OECD countries

\section{A. Gini coefficients}

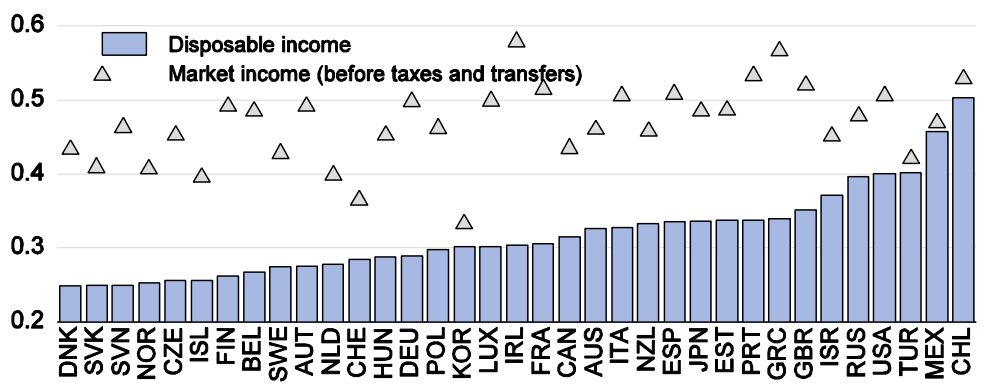

B. The share of the top decile in total wealth

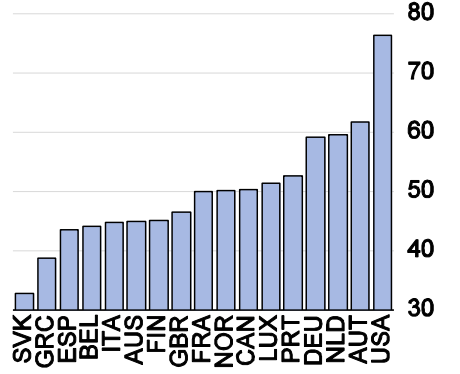

Note: The Gini coefficient takes values between 0 for full equality (all households receive the same income) to 1 for full inequality (one household receives all income).

Source: OECD Income Distribution and Poverty Database; and OECD Wealth Distribution Database.

Cyclical fluctuations could also affect income and wealth inequality. These effects seem to be stronger for income than wealth inequality (Box 1).

Some degree of inequality is unavoidable and it may stimulate investment and innovation (Cournède et al., 2015), but high inequality may reduce economic growth by reducing investment in human capital, especially for the bottom $40 \%$ of income earners (OECD, 2015). This is because poorer families may not be able to borrow to pay for high-quality education or retraining, or keep children in education for as long as is optimal. Also, poorer families cannot access finance to take advantage of business investment opportunities that could boost growth and their income (OECD, 2015; Denk and Cournède, 2015). 
Economic inequality may also contribute to financial instability. This link was suggested in the aftermath of the Great Recession for the United States (Rajan, 2010; Bordo and Meissner, 2012; and Kumhof et al., 2015). Poorer and low-income households aspire to increase consumption, reflecting a consumption externality "keeping up with the Joneses" (van Treek, 2014). With stagnant incomes, higher consumption can only be achieved by borrowing. Under poor prudential regulation, the resulting excessive leverage makes the financial system vulnerable to negative shocks. When such shocks materialise, disruptive deleveraging aggravates economic recession. This hypothesis is, however, debatable (Atkinson and Morelli, 2011), and income inequality does not seem to have increased household leverage in the euro area (Denk and Cournède, 2015).

\section{Box 1. Income and wealth inequality during the Great Recession}

Business cycle fluctuations can affect income inequality as various income sources, which differ in importance across the income distribution, can be affected differently (Figure A1 in Annex). For instance, Heathcote et al. (2010) report that in the United States earnings of the lowest-income individuals are most responsive to business cycle fluctuations. However, rising income inequality in recessions could be mitigated by larger declines in profits compared with wages, with profits being more important for households at the top of the income distribution. Moreover, households at the bottom of the distribution gain proportionally more from higher social transfers. Indeed, the US experience during the Great Recession suggests that the economic slowdown hit income from business activities and dividends more than wages, and boosted social transfers. ${ }^{1}$

Inequality in market income increased in most OECD countries during the Great Recession as measured by changes in the Gini coefficient (figure below). However, taxes and transfers mitigated the impact of the crisis on disposable income inequality. The Gini coefficients for disposable income increased by less, and in some countries they even declined. This seems to reflect the activation of unemployment benefits and other income-related benefits in response to the crisis. Inequality widened more in countries with larger increases in unemployment rates, especially for market income as is evident in the steeper slope of the line in Panel B than in Panel C of the figure below. This highlights the importance of maintaining high employment to limit the widening of the market income distribution and the role of the tax-transfer system in moderating the impact of the increase in market income inequality on disposable income inequality. Inequality for market income further increased between 2010 and 2012 in a number of OECD countries, including France, Italy and the United States.

OECD countries experienced large declines in asset prices during the Great Recession, followed by strong gains in some of them, partly reflecting extraordinary monetary policy stimulus via quantitative easing. These asset price changes likely affected the net wealth distribution (second figure below). To gain insights into the direction and magnitude of such effects, stylised calculations of changes in net wealth inequality measures implied by actual changes in asset prices between 2007 and 2010, and subsequently between 2010 and 2015, have been undertaken. ${ }^{2}$ No changes in asset volumes are assumed. These calculations are based on actual net wealth distributions measured with the 2012 Canadian Survey of Financial Security, the 2010 ECB Household Finance and Consumption Survey, the 2010-12 UK Wealth and Assets Survey by the Office for National Statistics, and the 2007 and 2010 US Federal Reserve Survey of Consumer Finances.

For the countries where the value of total assets declined due to house and equity prices falls, ${ }^{3}$ wealth inequality is estimated to have decreased in France, Italy and the United Kingdom, but it is estimated to have increased in the Netherlands and the United States. In the latter case, this stems from particularly high leverage of households at the bottom of the net wealth distribution, in contrast with the top of the distribution (Table A1 in Annex; Section 3.2). In Belgium, Canada and Germany, total assets increased due to the rise in house and bond prices (despite falls in equity prices). This is estimated to have increased net wealth inequality in Germany but reduced it in Belgium and Canada. The differentiated outcome is explained by a more skewed distribution of real estate relative to equities in Germany than in Belgium and Canada. 
Box 1. Income and wealth inequality during the Great Recession (Cont.)

\section{Evolution of income inequality during the Great Recession}

\section{A. Changes in the Gini coefficient, 2007-10}
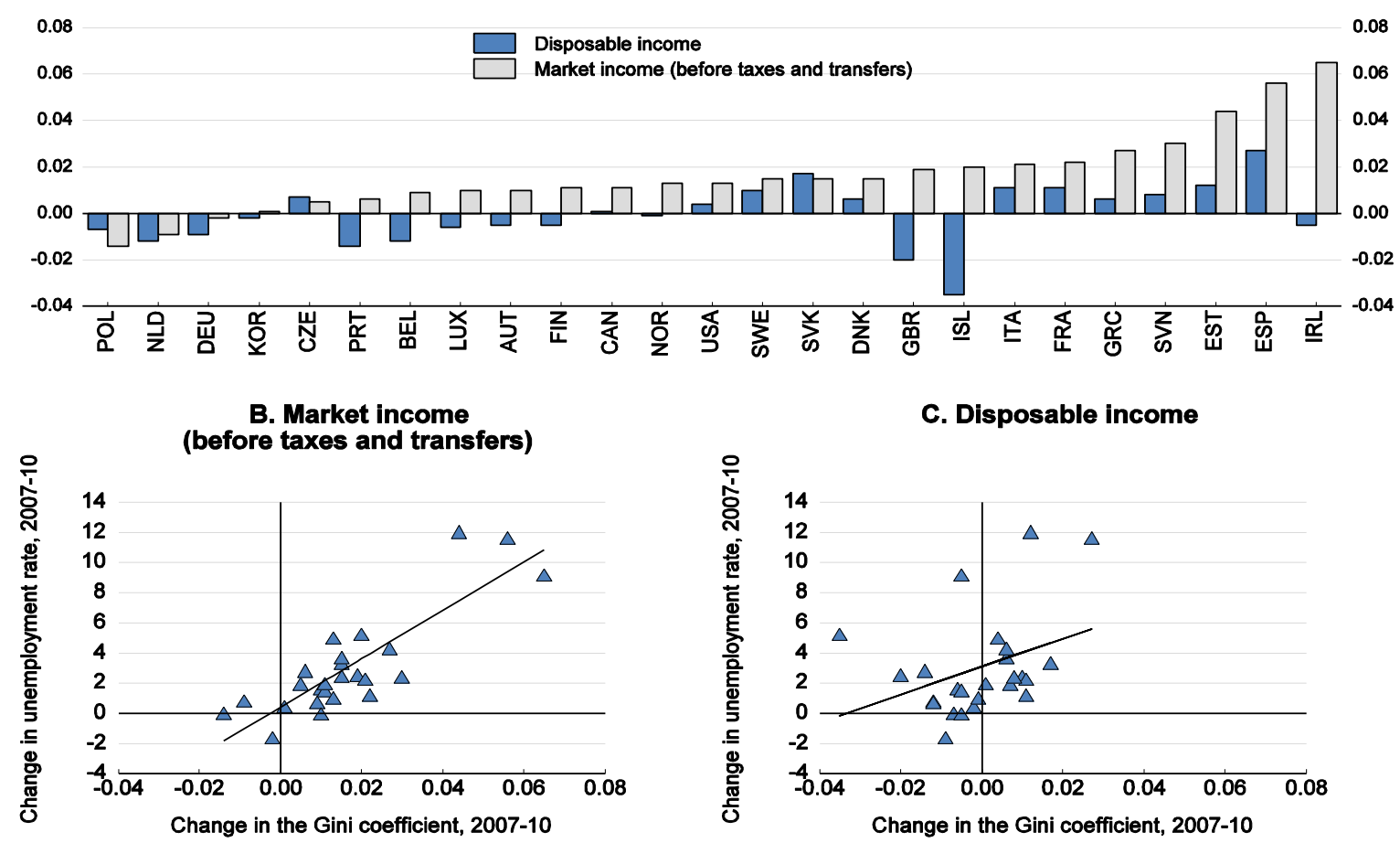

\section{Dlsposable Income}

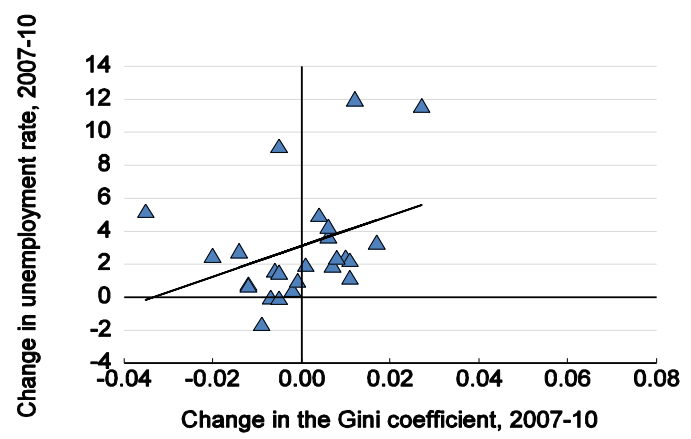

Note: The Gini coefficient takes values between 0 for full equality (all households receive the same income) to 1 for full inequality (one household receives all income).

Source: OECD Income Distribution and Poverty Database; and OECD Economic Outlook 98 database.

In all the analysed countries, implied changes in the three inequality measures are relatively small, even for the Netherlands and the United States. For instance, in the United States, the implied increase in the mean-to-median ratio was only around one-third of the actual increase between 2007 and 2010. In the United States, the direction of changes in inequality is consistent with the actual data for 2007 and $2010 .^{4}$

The evolution of asset prices since 2010 is estimated to have had the opposite effects on the net wealth distribution than in the 2007-10 period in all countries examined but in Canada, the Netherlands and the United Kingdom. In the Netherlands, inequality continued to increase given the sustained appreciation of total assets, and in Canada and the United Kingdom inequality declined further as households in the middle of the net wealth distribution gained most from the appreciation of total assets. Overall, the combined asset price changes since 2007 are estimated to have increased net wealth inequality in the Netherlands and the United States, left it broadly unchanged in Italy and France, and reduced it in Belgium, Canada, Germany and the United Kingdom.

The Great Recession experience indicates that cyclical fluctuations can have a significant impact on income inequality but not necessarily on net wealth inequality. This suggests that macroeconomic policies, including monetary policy, play a role in limiting the cyclical volatility in income inequality. In particular, expansionary monetary policy in a downturn could limit increases in wage inequality. This is supported by empirical evidence for the United States. ${ }^{5}$ Several pieces of empirical evidence suggest that this was indeed the case in the Great Recession. ${ }^{6}$ 


\section{Box 1. Income and wealth inequality during the Great Recession (cont.)}

Asset price changes during and after the Great Recession and implied changes in net wealth inequality

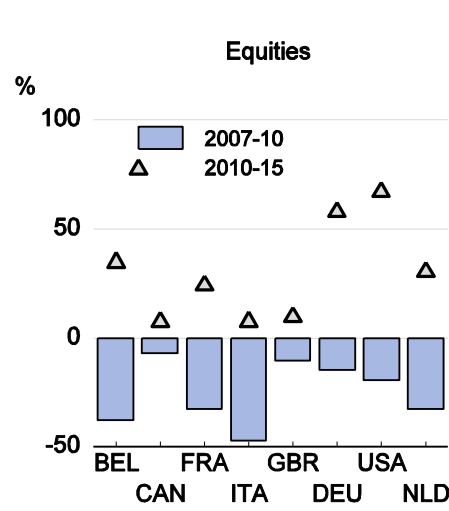

\section{A. Percentage change in assets prices}

$\%$

40

30

20

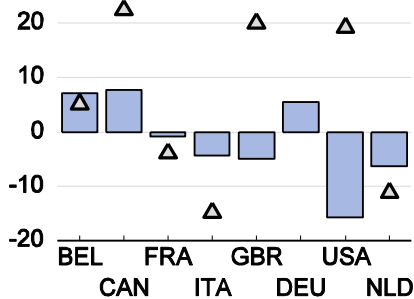

$\%$

20

$15 \Delta \quad \Delta$

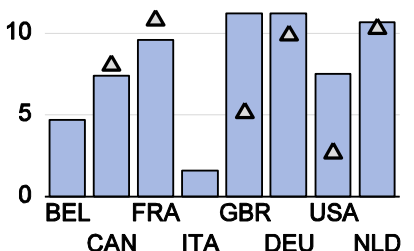

$B$. Absolute change in net wealth inequality indicators ${ }^{2}$ Share of the top decile in total net wealth Mean-to-median net wealth ratio
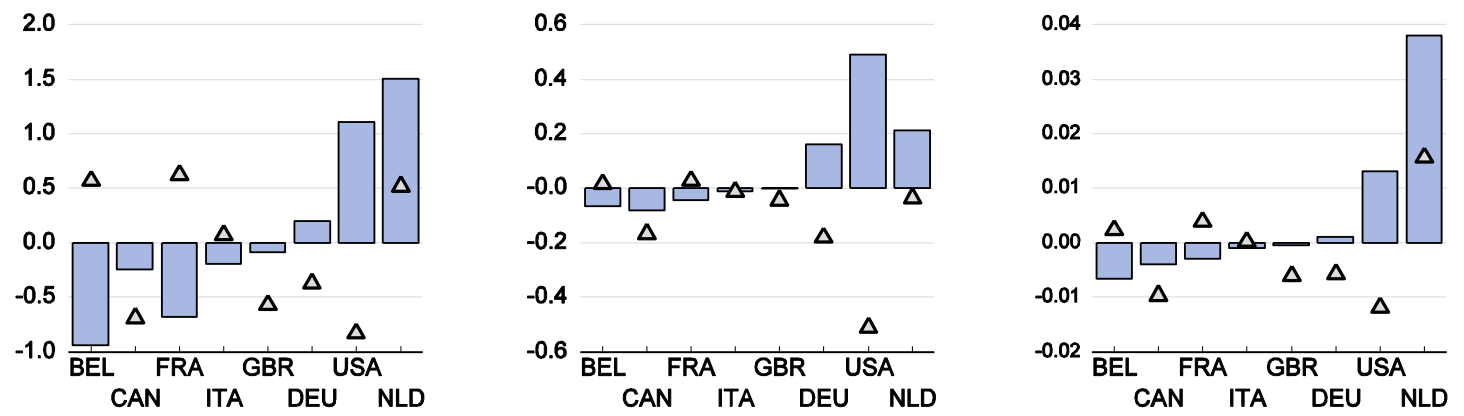

1. Based on 5-year sovereign bonds.

2. The change resulting from respective asset price changes as depicted in panel $A$.

Source: Bloomberg; Thomson Reuters; Statistics Canada Survey of Financial Security (2012); European Central Bank Household Finance and Consumption Survey (2010); UK Wealth and Assets Survey by the Office for National Statistics (2010-2012); US Federal Reserve Survey of Consumer Finances (2007 and 2010); OECD House Price Database; and authors' calculations.

1. According to the US Federal Reserve Survey of Consumer Finances, between 2007 and 2010 in nominal terms, average wages declined by around $5 \%$, and income from dividends by around twice as much and income from business activities around three times as such, while average transfers increased by $50 \%$.

2. The lack of wealth inequality time series, covering the period since the beginning of the Great Recession, in OECD countries, with the exception of Canada, the United Kingdom and the United States, precludes a factual analysis of trends in wealth inequality during this period.

3. Wealth survey implies that housing is a dominant asset (in contrast with national account data - Section 4.4), while bonds have a negligible share in total assets for most deciles.

4. According to the US Survey of Consumer Finances, the percentage decline in mean net worth was largest in the second quintile, while mean net worth in the top decile changed very little. As a result, the ratio of mean to median net wealth increased significantly, recording its biggest rise since 1989.

5. Interest increases by the Federal Reserve had a disproportionate effect of increasing unemployment rates for minorities and less-skilled workers (Carpenter and Rodgers III, 2004). Contractionary monetary policy raises labour income at top deciles, which may be linked with differences in the substitutability of skilled and unskilled labour with capital (Coibion et al., 2012). By and large, contractionary monetary policy in the United States increases total income inequality (Coibion et al., 2012).

6. Monetary policy easing is estimated to have lowered the unemployment rate by $1 \frac{1}{4}$ percentage points (Engen et al., 2015). This could have reduced the Gini coefficient by 0.5 Gini point (i.e. a reduction in the Gini coefficient of 0.005 ) based on panel estimates of determinants of pre-tax and transfer Gini coefficients in Huber and Stephens (2014) or by 0.8 Gini point based on the relation depicted in Panel $B$ of the first figure in this box. 


\section{Effects of monetary policy on inequality via interest rates and asset prices}

\subsection{Challenges with the assessment}

Assessing the direct impact of monetary policy on income and net wealth inequality via interest rates and asset prices is conceptually challenging for four reasons.

- While monetary policy affects macroeconomic aggregates, which influence income and net wealth distributions, quantifying its exact impact on these aggregates is difficult, especially for quantitative easing. This reflects, among other things, challenges with singling out pure monetary policy shocks from reactions of real and nominal variables to other shocks hitting the economy and responses of monetary policy to these shocks. Even so, the effects of changes in policy interest rates on asset prices have been extensively researched. Country-specific estimates vary considerably among studies, indicating a high degree of uncertainty. Conventional monetary policy is generally found to affect equity prices to a greater extent than house prices. ${ }^{5}$ Unconventional monetary policy measures are less researched, and there is less agreement about their effects. ${ }^{6}$ Another source of uncertainty about monetary policy effects stems from the fact that they are likely to vary over time, depending on the phase of a cycle (see below) and the functioning of the financial sector and product and labour markets.

- The direct effects of monetary policy on income and wealth inequality can go in opposite directions over different phases of a business cycle. In a downturn, monetary policy easing is expected to reduce income inequality (i.e. to lessen the downturn-related increase in income inequality). At the same time, the easing is expected to raise asset prices from downturn-induced subdued levels and thus potentially increase net wealth inequality (i.e. limit the downturninduced reduction in wealth inequality), if rising asset prices make the distribution of net wealth more unequal. This tends to be the case for equities and bonds but not for real estate (Section 3.2). The opposite effects are expected when monetary policy is tightened in the boom phase.

- The role of monetary policy should be viewed against a counterfactual with no change of the monetary policy stance (Bivens, 2015). In the absence of monetary policy intervention, a larger variation in inequality over the business cycle would be likely.

- Monetary policy could have longer-term effects over several business cycles. In theory, with symmetric cycles - both in terms of the duration and amount of stimulus/contraction - and symmetric effects of policy changes, monetary policy should have no long-term impact on income and wealth inequality. However, empirical evidence does not support the theory for a variety of reasons.

5. A 100-basis point fall in policy rates is estimated to boost US and UK house prices temporarily by between 2\% and 4\% (Aoki et al., 2002; Aoki et al., 2004; and Aladangady, 2015), but there is little evidence about longer-term effects (Dobbs et al., 2013). The same monetary policy easing increases equity prices by between 4\% and 10\% (Rigobon and Sack, 2004; and Bernanke and Kuttner, 2005).

6. For instance, quantitative easing is generally found to have increased prices of government bonds, but the size and duration of these effects are highly uncertain (Martin and Milas, 2012). Implications for other asset classes, real GDP growth and inflation are less researched and there is less supportive evidence that quantitative easing affected them. 
- The effectiveness of monetary policy tends to differ over the business cycle. Monetary policy tightening may slow the economy more than an equivalent monetary policy easing strengthens the economy (Morgan, 1993; and Karras, 1996). ${ }^{7}$ This could require asymmetric monetary policy over the cycle to stabilise the economy. Such asymmetric monetary policy effects seem to exist not only for real GDP growth but also for nominal variables (Tenreyro and Thwaites, 2013). The asymmetric effectiveness may imply that monetary policy is less effective in reducing income inequality during downturns than it is in increasing income disparities in upturns. In this context, symmetric monetary policy may thus contribute to rising income inequality over the whole business cycle.

- Empirical studies suggest that monetary policy tends to react more to declines than to increases in equity prices (Ravn, 2012; 2014). ${ }^{8}$ This asymmetry may thus contribute to a secular rise in wealth inequality, as equity prices are prevented from falling too much in downturns, but their increases are not tempered in booms. This effect is, however, difficult to quantify in practice.

\section{2. $\quad$ Stylised examples}

Interactions between monetary policy, via changes in interest rates and asset prices, and income and wealth inequality are complex. They depend on multiple dimensions related to relative sizes and distributions of specific types of assets and liabilities. To help understand these interactions, this section presents stylised examples to illuminate key factors that determine the sign and size of monetary policy effects on income and wealth inequality.

Although monetary policy could affect inequality via various channels, the simulations focus on impacts via changes in domestic interest rates and asset prices only. For the sake of simplicity, it is assumed that changes in the monetary policy stance show up fully in changes in all interest rates relevant for households, both on the liability and asset side. It is also assumed that households have no foreign assets, implying no role for exchange rates; that there are no other effects via real and nominal variables, such as unemployment, output, consumer prices and rental income; and that households do not reallocate their asset portfolios in response to asset price changes. Thus, the simulated effects could be smaller than what is likely in reality. These assumptions also imply that with policy interest rates at the effective zero lower bound and monetary stimulus implemented via quantitative easing, monetary policy is likely to affect wealth inequality more than income inequality. This reflects the fact that interest rates, especially at shorter maturities, cannot fall much, while asset prices can increase substantially.

The implications for income inequality are based on assets and liabilities distributions by income quintiles, while implications for wealth inequality on corresponding distributions by net wealth quintiles. Regarding income distribution effects, the simulations refer to gross income as reported in household surveys, which includes market income, including property income, and transfers but does not account for taxes and debt servicing costs. The simulations of interest rate cuts also involve marginal changes to debt servicing costs, and in this sense they refer to the disposable income concept.

7. The limited effectiveness of monetary policy in the downturn can be explained by the fact that prices are less flexible downwards than upwards, and by confidence and credit channels, which are more detrimental to growth in recessions than they are supportive to growth in booms. Empirical evidence indicates that the credit channel (financial accelerator hypothesis) is more relevant in bad times (Gertler and Glichrist, 1994; and Peersman and Smets, 2005).

8. In the United States, this relates to the finding that the FOMC is likely to react more if there are concerns about financial stability (Peek et al., 2015), which may correlate with asset price declines. 
In view of the simplified nature of the simulations, inequality is measured by the mean-to-median (M2M) ratio, the ratio of $5^{\text {th }}$ quintile to the $3^{\text {rd }}$ quantile $(\mathrm{Q} 5 / \mathrm{Q} 3)$, and the ratio of $5^{\text {th }}$ quintile to the $1^{\text {st }}$ quantile (Q5/Q1), while Gini coefficients are not calculated. The higher the measures are, the more unequal is the distribution. These measures are, however, problematic for some cases. The M2M ratio is insensitive to small changes in the distribution, whereas the Q5/Q1 ratio reacts strongly to minute changes when the bottom quintile is close to zero. Also, when households in the middle of the distribution (relative to the top) are affected differently than households at the bottom of the distribution, then the Q5/Q1 and Q5/Q3 measures can move in the opposite direction.

\section{Income distribution effects with interest-paying assets and liabilities}

The simulated income distribution effects stemming from lower interests rates take into account only reduced returns on interest-paying assets and lower debt servicing costs, while potential effects via dividends are analysed separately below. In practice, these effects work only via interest-paying assets and variable-interest rate debt that are directly held by households, which are usually only a small fraction of total household assets and liabilities (Section 4.4). Moreover, at any point in time, they depend on the speed of the pass-through from policy rates to returns on assets and to the cost of debt. On the asset side, for instance, lower bond yields are passed through to income only when bonds held by households mature and new bonds are purchased. Thus, the speed is determined by the maturity structure of bonds. On the liability side, the prevalence of variable-rate mortgages accelerates the pass-through. However, even with fixed-rate mortgages, households can possibly re-mortgage and benefit from lower interest rates, though this may take more time (and be asymmetric). The simulations below assume that all assets pay interest and all liabilities are at variable rates.

Figure 3. Determinants of interest rate cut effects on the income distribution

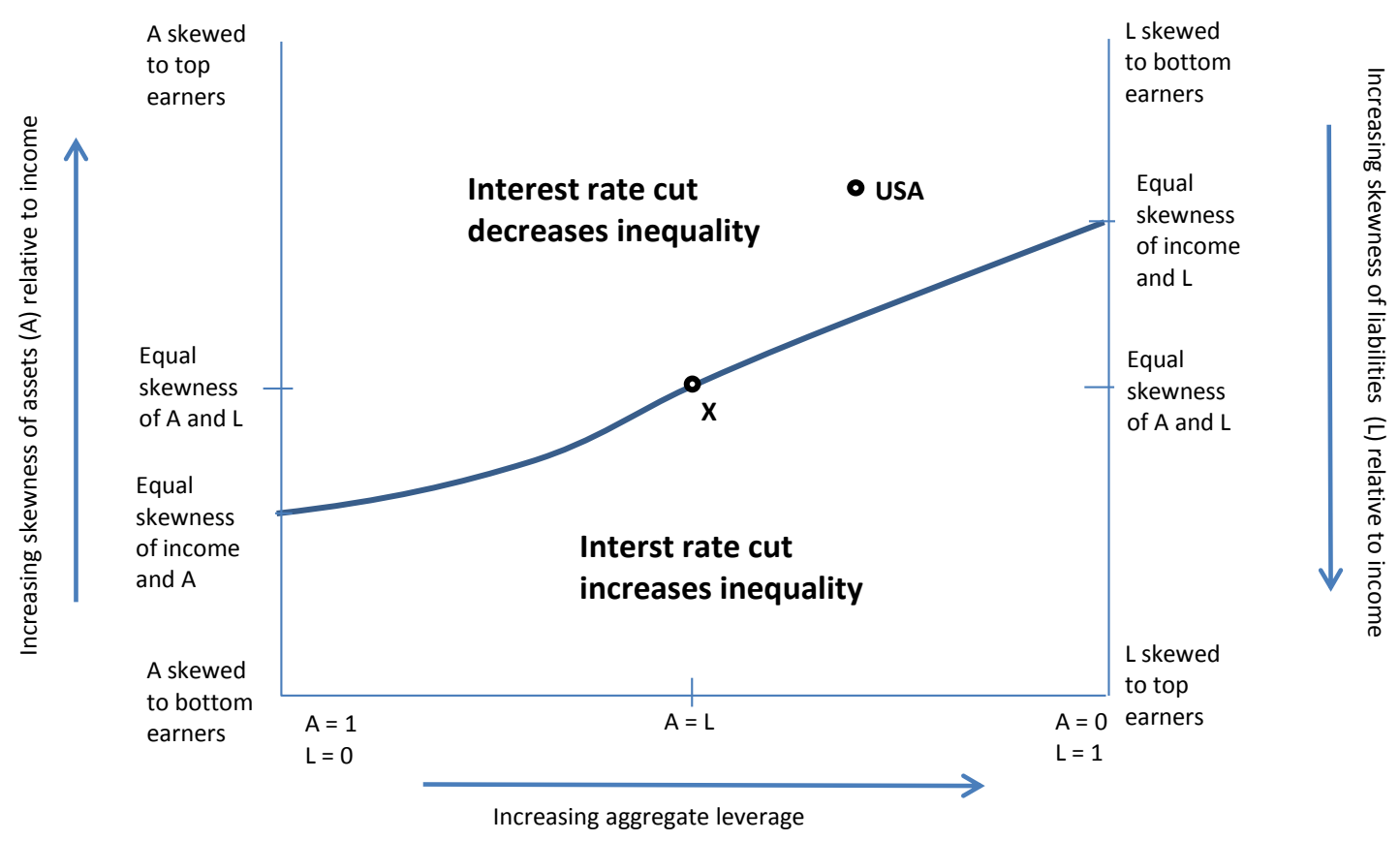

Note: The upward-sloping line represents where the skewness of income is equal to that of net wealth. The skewness of income is assumed fixed. Point $X$ represents where assets and liabilities are identical in size and distribution. The slope of the line depends on the skewness of income. It is downward-sloping when the skewness of income is high. The size of assets and liabilities on the horizontal axis are normalised to 1. The extreme point on the left holds for any assets greater than zero and no liabilities and the extreme point on the right holds for any liabilities greater than zero and no assets. An example of the United States is shown, based on actual sizes and distributions of interest-paying assets and liabilities.

Source: Authors' calculations. 
Monetary policy effects on income inequality are not clear a priori. The impact of interest rate cut on the income distribution depends on the relative size and distributions of assets and liabilities (Table 1 and Figure 3). The upward sloping line in Figure 3 shows where the shares of interest-paying assets minus liabilities (by income quantile) ${ }^{9}$ are equal to that of income shares (by quantile) and there is no effect on the income distribution. ${ }^{10}$

- In the area above the line, net wealth is more skewed (to high-income groups) than income, so a fall in interest rates reduces inequality. This happens when:

- Liabilities are sufficiently large relative to assets, and liabilities are less skewed to top earners than income. This stems from lower-income households benefiting more from lower debt servicing costs (net of lower returns on assets).

- Assets are sufficiently large (relative to liabilities), and more skewed to top earners than income.

- In the area below the line, net wealth is less skewed than income, so lower interest rates increases inequality. This happens when:

Table 1. Stylised effects of a 4-percentage point interest rate cut on income inequality

\begin{tabular}{|c|c|c|c|c|c|c|c|c|c|c|c|}
\hline \multirow[b]{2}{*}{$\underline{\mathrm{IR}}$} & \multirow[b]{2}{*}{ Assets } & \multirow[b]{2}{*}{ Liabilities } & \multirow{2}{*}{$\begin{array}{l}\text { Q5/Q3 } \\
\text { income }\end{array}$} & \multirow{2}{*}{$\begin{array}{l}\text { Q5/Q1 } \\
\text { income }\end{array}$} & \multirow{2}{*}{$\begin{array}{c}\text { M2M } \\
\text { income }\end{array}$} & \multicolumn{3}{|c|}{ Mean-to-median (M2M) } & \multicolumn{3}{|c|}{ Percent change in income inquality } \\
\hline & & & & & & assets & liabilities & net wealth & Q5/Q3 & Q5/Q1 & M2M \\
\hline & \multicolumn{11}{|c|}{ No effect } \\
\hline 0.04 & 100 & 100 & 3.17 & 9.50 & 1.33 & 1.33 & 1.33 &.. & 0.0 & 0.0 & 0.0 \\
\hline 0.04 & 100 & 100 & 3.17 & 9.50 & 1.33 & 2.50 & 2.50 & & 0.0 & 0.0 & 0.0 \\
\hline 0.04 & 100 & 100 & 3.17 & 9.50 & 1.33 & 1.18 & 1.18 &.. & 0.0 & 0.0 & 0.0 \\
\hline 0.04 & 150 & 100 & 3.17 & 9.50 & 1.33 & 1.33 & 1.33 & 1.33 & 0.0 & 0.0 & 0.0 \\
\hline 0.04 & 100 & 150 & 3.17 & 9.50 & 1.33 & 1.33 & 1.33 & 1.33 & 0.0 & 0.0 & 0.0 \\
\hline \multicolumn{12}{|c|}{ Reducing income inequality } \\
\hline 0.04 & 100 & 100 & 3.17 & 9.50 & 1.33 & 3.64 & 2.18 &.. & -2.9 & -4.4 & -1.0 \\
\hline 0.04 & 150 & 100 & 3.17 & 9.50 & 1.33 & 2.50 & 2.50 & 2.50 & -1.9 & -2.1 & -0.9 \\
\hline 0.04 & 150 & 100 & 3.17 & 9.50 & 1.33 & 3.64 & 2.18 & -3.24 & -5.6 & -7.7 & -2.2 \\
\hline 0.04 & 100 & 150 & 3.17 & 9.50 & 1.33 & 1.18 & 1.18 & 1.18 & -0.9 & -5.1 & -0.3 \\
\hline 0.04 & 100 & 150 & 3.17 & 9.50 & 1.33 & 3.64 & 2.18 & 1.41 & -1.6 & -3.2 & -0.2 \\
\hline \multicolumn{12}{|c|}{ Increasing income inequality } \\
\hline 0.04 & 100 & 100 & 3.17 & 9.50 & 1.33 & 2.18 & 3.64 & & 2.9 & 4.6 & 1.0 \\
\hline 0.04 & 150 & 100 & 3.17 & 9.50 & 1.33 & 1.18 & 1.18 & 1.18 & 0.9 & 5.9 & 0.3 \\
\hline 0.04 & 150 & 100 & 3.17 & 9.50 & 1.33 & 2.18 & 3.64 & 1.41 & 1.7 & 3.4 & 0.2 \\
\hline 0.04 & 100 & 150 & 3.17 & 9.50 & 1.33 & 2.50 & 2.50 & 2.50 & 1.8 & 2.1 & 0.9 \\
\hline 0.04 & 100 & 150 & 3.17 & 9.50 & 1.33 & 2.18 & 3.64 & -3.24 & 5.7 & 8.1 & 2.2 \\
\hline
\end{tabular}

Note: The higher the mean-to-median (M2M), $5^{\text {th }}$ quantile to $3^{\text {rd }}$ quantile $(\mathrm{Q} 5 / \mathrm{Q} 3)$ and $5^{\text {th }}$ quantile to $1^{\text {st }}$ quantile (Q5/Q1) ratios, the more unequal is the distribution. Thus, the positive changes in these ratios imply increased inequality and vice versa.

Source: Authors' calculations.

9. Due to the presence of negative values, defining the inequality of the net wealth distribution is problematic. For the purpose of this section, negative net wealth that is skewed toward top (bottom) income groups is considered equivalent to positive net wealth skewed toward bottom (top) income groups.

10. The slope and shape of the line is purely illustrative. Two knife-edge scenarios include where the distributions of assets and liabilities are equal and: $i$ ) both the level of assets and liabilities are equal (point X); and ii) the level of assets and liabilities differ, but the distribution of assets and liabilities are also equal to that of income (not shown in Figure 3). In these situations a change in policy rates has no effect on inequality (Table 1). 
- Liabilities are sufficiently large relative to assets, and liabilities are more skewed to top earners than income.

- Assets are sufficiently large relative to liabilities, and less skewed to top earners than income.

The size of the effects depends on the magnitude of interest rate changes.

In Box 2, actual distributions and sizes of income, interest-paying assets, and liabilities are used to assess the income distribution impact of interest rate changes. The results suggest that lower interest rates reduce income inequality in Canada, the Netherlands and the United States but increase it in most European countries. However, the key result is that the effects are small. This may reflect the fact that returns from interest-paying financial assets and debt servicing costs account for only a small proportion of household income (Figure A1 in Annex), especially as financial assets and liabilities are underreported in household wealth surveys compared with national accounts data (Section 4.4).

The effects of monetary policy on the income distribution would be larger when its stabilising effects on employment are accounted for. For instance, a monetary policy-induced lowering of the unemployment rate by 1 percentage point could reduce the Gini coefficient for market income by around 0.4 Gini point (Huber and Stephens, 2014). This could offset the increase in income inequality due to lower interest rates in many euro area countries examined and the United Kingdom and reduce income inequality in Canada and the United States by substantially more than as a result of changes in net interest income alone. This is consistent with the findings for Italy (Casiraghi et al., 2016). Monetary policy easing in the euro area is estimated to have reduced income inequality for Italian households via its stimulus to economic activity and employment by more than it is estimated to have increased income inequality via interest income and debt servicing costs.

\section{Box 2. Does monetary policy affect income inequality via returns on net wealth?}

This box examines if changes in interest rates due to conventional monetary policy or quantitative easing can have an economically significant direct impact on household income and in turn on income inequality and consumption. The focus is exclusively on the effects via returns on financial assets and the cost of debt servicing. No account is taken for effects via dividends, rental income, employment, prices, GDP growth and exchange rates.

The impact of lower policy rates on household income and its distribution, via reduced debt servicing costs and returns on assets, is analysed in a stylised scenario. It assumes that interest rates are cut by 1 percentage point and that there is full and immediate pass-through to interest payments on total outstanding debt and to returns on interestpaying assets in each household income decile. Therefore, estimates serve as an upper bound for the direct impact, when the net effect is positive. The results are symmetric for interest rate increases. The distribution of debt and interest-paying assets ${ }^{1}$ by income deciles are taken from household wealth surveys (Box 1).

The changes in income stemming from lower interest rates have a very limited net impact on the income distribution. With the 1-percentage point cut in interest rates, Gini coefficients change by 0.4 Gini point in Belgium and at most by 0.15 Gini point in other countries (table below). These changes are only a tiny fraction of changes observed during the Great Recession for all countries but Belgium and Germany, even if the interest rate declines by 4 percentage points. Despite much debt being fixed rate, it is assumed that there is full pass-through. Therefore the effects of lower interest payments on debt are larger than is likely to be the case (and in some countries the direction of the net effect is likely to change sign). The very small impact stems from the fact that there is a weak relationship between debt/income ratios and the position in the income distribution, even if the rank correlation between income and debt (ranging from 0.22 to 0.43 ) implies that those with high debt generally have high income. Similarly, on the asset side, although high-income households are more likely to hold interest-paying assets, it is the share of interest earnings in income which determines how inequality is affected.

The direction of changes in the Gini coefficient - both due to lower debt servicing and lower returns on assets vary across countries, reflecting differences in the distribution of interest-paying assets and total debt across income deciles (Section 4.4). Lower interest rates tend to reduce income inequality in Canada, the Netherlands ${ }^{2}$ and the United States on net, while increase it in the remaining countries. 
Box 2. Does monetary policy affect income inequality via returns on net wealth? (cont.)

Changes in Gini coefficients for the income distribution due to lower interest rates

\begin{tabular}{lrrrrrrrr} 
& Belgium & Canada & France & Germany & $\begin{array}{c}\text { Nether } \\
\text { Italy }\end{array}$ & $\begin{array}{c}\text { United } \\
\text { Kingdom }\end{array}$ & $\begin{array}{c}\text { United } \\
\text { States }\end{array}$ \\
\hline Gross income Gini & 0.4873 & 0.4469 & 0.3840 & 0.4292 & 0.3980 & 0.3126 & 0.4264 & 0.5742 \\
Changes in Gini with 1 p.p. lower interest rates & 0.0039 & -0.0001 & 0.0007 & 0.0009 & 0.0000 & -0.0009 & 0.0010 & -0.0015 \\
Changes in Gini with 4 p.p. lower interest rates & 0.0265 & 0.0016 & 0.0040 & 0.0046 & 0.0007 & 0.0015 & 0.0067 & -0.0037 \\
Memorandum & & & & & & & & \\
Changes in market income Gini, 2007-10 & 0.0090 & 0.0110 & 0.0221 & -0.0020 & 0.0210 & -0.0085 & 0.0190 & 0.0132 \\
\hline
\end{tabular}

Source: OECD Income Distribution and Poverty Database; and authors' calculations.

The resulting consumption effects are derived from the decile-specific marginal propensity to consume (MPC) as estimated by Carroll et al. (2014a and 2014b) (Table A2 in Annex). ${ }^{3}$ As consumption data are not available from the surveys used, percentage increases are calculated by dividing the simulated aggregate consumption increase by aggregate consumption taken from national accounts for the same year as the survey. Overall, the consumption increase as a result of direct income gains due to a 1 point cut to interest payments is small (table below). The aggregate MPCs implied are low compared to other studies, and so the reported effects may be significantly smaller than is actually the case. But even with this caveat, the effects are minor. In most analysed countries, the net effect on consumption is positive, consistent with empirical evidence for the United States and the United Kingdom (Aron et al., 2012). Belgium is an exception where the negative net effect reflects large interest-paying assets in relation to income (Figure 6). Given the minor importance of the income effect, changes in the distribution of income or net wealth are unlikely to have a significant effect on monetary policy transmission (Section 4.1).

\section{Impact of a 1-percentage point decline in interest rates on consumption}

Per cent change

\begin{tabular}{lrrrrrrrr} 
& Belgium & Canada & France & Germany & Italy & $\begin{array}{c}\text { Nether- } \\
\text { lands }\end{array}$ & $\begin{array}{c}\text { United } \\
\text { Kingdom }\end{array}$ & $\begin{array}{r}\text { United } \\
\text { States }\end{array}$ \\
\hline Consumption effect: lower debt payments & 0.0007 & 0.0014 & 0.0007 & 0.0013 & 0.0003 & 0.0023 & 0.0012 & 0.0018 \\
Consumption effect: lower interest income & -0.0015 & -0.0005 & -0.0004 & -0.0010 & -0.0003 & -0.0006 & -0.0007 & -0.0007 \\
Net consumption effect & -0.0008 & 0.0010 & 0.0003 & 0.0003 & 0.0000 & 0.0017 & 0.0005 & 0.0011 \\
\hline
\end{tabular}

Source: Authors' calculations.

1. For Canada, they include all deposits, bonds, and savings accounts. For euro area countries, interest paying-assets include savings accounts (excluding sight accounts), bonds, and mutual funds invested mainly in bonds and money markets. For the United Kingdom, they include savings accounts, national savings products, bonds, and cash investment savings accounts. For the United States, they include call and savings accounts (excluding checking accounts), bonds, and mutual funds invested in bonds.

2. In Canada and the Netherlands, the Gini coefficients decline when interest rates are cut by 1 percentage point but increase when rates are cut by 4 percentage points. Income inequality rises as some households with initially very large debt but low assets and low incomes gain massively from the large interest rate cut, shifting them to top deciles and increasing their income compared with lower decile households. This may reflect incorrectly reported debt. Alternatively, the assumption of a full pass-through of interest rate cuts to servicing cost may not be realistic, as these households may pay very low or no interest rates, for instance due borrowing from relatives. This effect is not present with small interest rate cuts.

3. Carroll et al. (2014a and 2014b) estimate MPCs using a calibrated buffer-stock model of consumption which models wealth as a function of permanent income. They are derived as response to a one-off "stimulus cheque", in the model where a transitory income shock and a permanent wealth shock are equivalent. The implied aggregate MPCs used are lower than typical estimates for transitory income shocks. Differences in the MPC whether the income shock is permanent or transitory are small for the top deciles. The methodology does not allow for different regulatory environments which may affect the MPC, especially out of housing wealth. Alternative estimates of MPC from wealth for France are considerably lower, though the MPC is also declining with wealth (Arrondel et al., 2015). Estimates based on microeconomic evidence tend to show larger MPC than those implied by macro models (Box 3; Carroll et al., 2014b). The MPCs for Canada and the United Kingdom are assumed to be the same as for the euro area aggregate. 


\section{Income distribution effects with dividend-paying assets and liabilities}

Monetary policy changes could also alter the income distribution by affecting dividends as equities are held primarily by high-income households. Lower interest rates may boost dividends over time as, ceteris paribus, firms' profits increase thanks to lower debt servicing costs and stronger economic activity. Thus, unlike in the above example with interest-paying assets, interest rate cuts benefit households both due to higher dividends and lower debt servicing costs.

In order to illustrate the determinants of the relation between interest rate changes and the income distribution, it is assumed that households hold liabilities (subject to interest payments) and dividendpaying assets (equities) but not interest-paying assets (as in the example above). Under these assumptions, an interest rate cut will always increase income inequality if liabilities and equities are more skewed to topearners than income, regardless of the relative sizes of equities and liabilities (Figure 4). ${ }^{11}$ These conditions hold in many countries as equity holdings are considerably more skewed than income in all countries examined, but this is not always the case for liabilities. In countries where liabilities are more equally distributed than income, a rise in income inequality following an interest rate cut occurs if households have sufficiently more equities than liabilities.

Figure 4. Determinants of interest rate cut effects on the income distribution with dividends

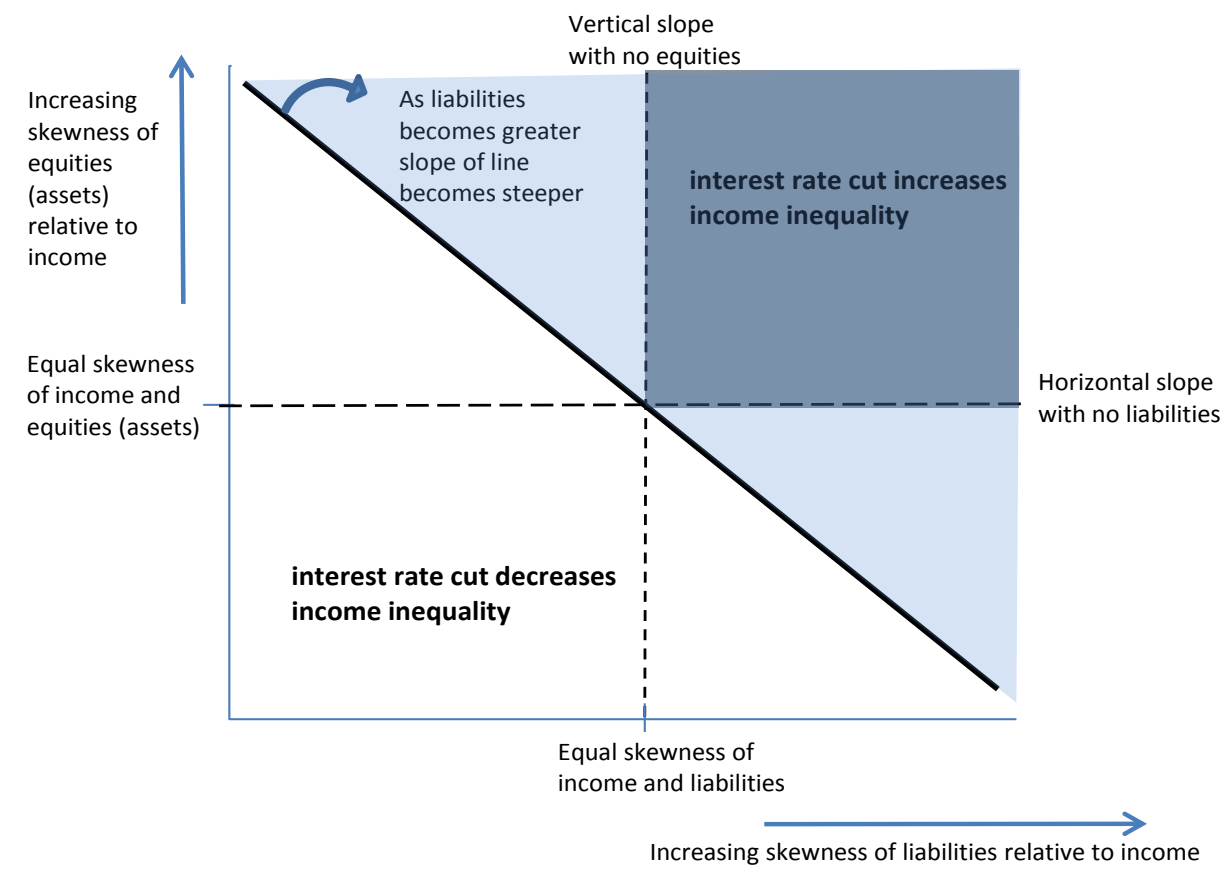

Note: The line represents a combination of relative skewness of debt and equites relative to income and relative sizes of debt and equities where the interest rate cut does not change the income distribution. The shaded area above the line indicates the respective combinations where the interest rate cut increases income inequality. This is when: debt and equities are more skewed to top-earners than income, regardless of the relative sizes of equities and debt (dark shaded area); equities are more skewed than income (and debt less skewed), and equities are sufficiently larger than debt (upper light shaded area); and equities are less skewed than income (and debt more skewed), and equities are sufficiently smaller than debt (lower light shaded area).

Source: Authors' calculations.

11. In this stylised illustration, the relative size of equities and liabilities is understood in terms of relative gains from assets and liabilities for a given change in the interest rate. For instance, the equality of equities and liabilities implies that a 1-percentage point cut in interest rates generates debt servicing savings equal in size to dividend gains. This may not be true in reality. 
The illustrative income distribution effects of interest rate cuts when all three channels are present (returns on interest-paying and dividend-paying assets and debt servicing costs) are complex. In a specific case, when interest-paying and dividend-paying assets are equal in size and distribution, income distribution effects will be entirely determined by the liability side (points on the vertical line on the right hand side in Figure 3).

\section{Net wealth distribution effects}

Assuming one composite asset and one composite liability, effects of an asset price change on net wealth inequality depend crucially on the relative distribution of assets and liabilities, which shape leverage across the distribution (Table 2):

- If there are no liabilities or if assets and liabilities are distributed in the same way (that is, leverage does not vary across the distribution), then the asset price change has no effect on the net wealth distribution. ${ }^{12}$

- If assets are more skewed to the top of the net wealth distribution than liabilities, a general rise in asset price reduces net wealth inequality. This stems from high leverage at the bottom of the net wealth distribution. Consequently, asset price appreciation increases net wealth for poor households more than for wealthy households. This effect is stronger the more differentiated are the distributions. ${ }^{13}$

Asset price changes can affect net wealth inequality differently when different asset classes vary in terms of their distribution and size. A stylised example below assumes that there are three assets (real estate, bonds and equities) in equal proportions (Table 3). ${ }^{14}$ As it is the case in most OECD countries, real estate is assumed to be less unequally distributed than bonds and equites, while the three assets are less equally distributed than liabilities. In this example, a $10 \%$ increase in house prices reduces inequality (according to mean-to-median and Q5/Q3 ratios). This is in contrast with corresponding increases in prices of bonds and equities, respectively, which raise inequality. ${ }^{15}$ As real estate is more equally distributed than bonds and equities, households in the middle of the distribution gain most from house prices increases in contrast to households at the top of the distribution who benefit most from equity and bond price gains. When prices of all three assets increase, net wealth inequality is reduced.

12. This is equivalent to the situation with many asset classes where prices of all assets change identically.

13. This effect does not depend on the relative size of assets and liabilities. This is in contrast to the case for income inequality detailed above.

14. This simplified assumption omits assets, like deposits, whose prices do not change with monetary policy and account for a significant share of households assets in reality.

15. This is broadly consistent with the simulations based on actual income and wealth distributions for the euro area countries. Adam and Tzamourani (2015) find that a 10\% increase in the value of housing decreases the euro area Gini coefficient for net wealth by 0.4 Gini point to 65.1 as housing tends to be held by middle deciles. In contrast, a $10 \%$ rise in equity prices increases the coefficient by 0.3 Gini point, while a change in bond prices has no effect, likely reflecting the very low share of bonds in total assets found in the wealth surveys. 
Table 2. Stylised effects of a $10 \%$ increase in asset prices on wealth inequality

\begin{tabular}{|c|c|c|c|c|c|c|c|c|c|c|c|c|c|}
\hline \multirow[b]{2}{*}{ A } & \multirow[b]{2}{*}{$\mathrm{L}$} & \multicolumn{3}{|c|}{ Q5/Q3 } & \multicolumn{3}{|c|}{ Q5/Q1 } & \multicolumn{3}{|c|}{ M2M } & \multicolumn{3}{|c|}{ Percent change in net wealth inequality } \\
\hline & & $\mathrm{L}$ & A & NW & $\mathrm{L}$ & A & NW & $\mathrm{L}$ & A & NW & Q5/Q3 & Q5/Q1 & M2M \\
\hline \multicolumn{14}{|c|}{ No effect } \\
\hline 600 & 이 & .. & 8.25 & 8.25 & .. & 16.50 & 16.50 & & 2.50 & 2.50 & 0.0 & 0.0 & 0.0 \\
\hline 600 & 100 & 8.25 & 8.25 & 8.25 & 16.50 & 16.50 & 16.50 & 2.50 & 2.50 & 2.50 & 0.0 & 0.0 & 0.0 \\
\hline \multicolumn{14}{|c|}{ Reducing net wealth inequality } \\
\hline 600 & 100 & 3.33 & 11.43 & 15.93 & 10.00 & 80.00 & 430.00 & 1.33 & 2.86 & 3.70 & -28.2 & -81.4 & -22.9 \\
\hline 600 & 100 & 2.50 & 30.00 & 250.00 & 4.00 & 90.00 & -125.00 & 1.25 & 6.67 & 50.00 & -88.0 & -172.0 & -86.7 \\
\hline \multicolumn{14}{|c|}{ Increasing net wealth inequality } \\
\hline 600 & 100 & 11.43 & 3.33 & 2.65 & 80.00 & 10.00 & 7.59 & 2.86 & 1.33 & 1.20 & 25.8 & 31.8 & 10.7 \\
\hline 600 & 100 & 30.00 & 2.50 & 1.61 & 90.00 & 4.00 & 2.54 & 6.67 & 1.25 & 1.08 & 55.0 & 57.3 & 16.3 \\
\hline
\end{tabular}

Note: $A$ stands for assets; $L$ stands for liabilities, and $N W$ stands for net wealth. The higher the mean-to-median (M2M), $5^{\text {th }}$ quantile to $3^{\text {rd }}$ quantile $(\mathrm{Q} 5 / \mathrm{Q} 3)$ and $5^{\text {th }}$ quantile to $1^{\text {st }}$ quantile $(Q 5 / Q 1)$ ratios, the more unequal is the distribution. Thus, the positive changes in these ratios imply increased inequality and vice versa.

Source: Authors' calculations.

Table 3. Stylised net wealth distribution effects with a different skewness of assets

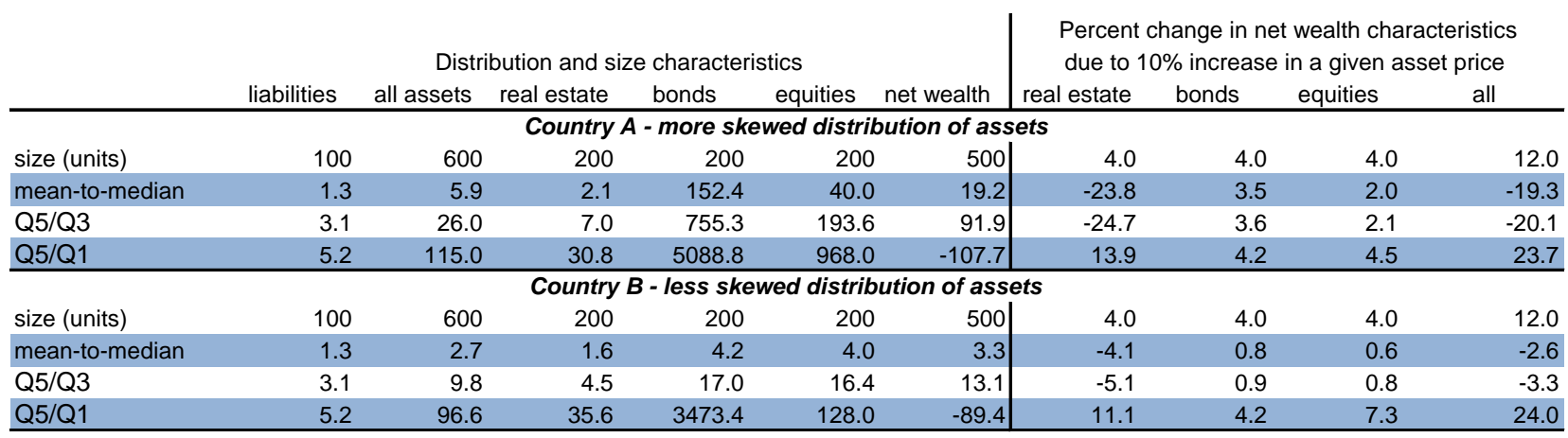

Note: The higher the mean-to-median (M2M), $5^{\text {th }}$ quantile to $3^{\text {rd }}$ quantile $(\mathrm{Q} 5 / \mathrm{Q} 3)$, and $5^{\text {th }}$ quantile to $1^{\text {st }}$ quantile (Q5/Q1) ratios, the more unequal is the distribution. Thus, the positive changes in these ratios imply increased inequality and vice versa. Both countries have the same skewness of liabilities. The distribution characteristics of country A are based on those of the United States and of country B on those of the euro area.

Source: Authors' calculations.

Table 4. Stylised net wealth distribution effects with different asset skewness, portfolios and price increases

\begin{tabular}{|c|c|c|c|c|c|c|c|c|c|c|c|}
\hline \multicolumn{12}{|c|}{\begin{tabular}{l|l} 
Percent change in net wealth characteristics \\
due to asset price increase by
\end{tabular}} \\
\hline & liabilities & all assets & $\begin{array}{l}\text { Distribution } \\
\text { real estate }\end{array}$ & $\begin{array}{l}\text { ind size cha } \\
\text { bonds }\end{array}$ & $\begin{array}{l}\text { racteristics } \\
\text { equities }\end{array}$ & other & net wealth & $\begin{array}{c}2 \% \\
\text { real estate }\end{array}$ & $\begin{array}{c}6 \% \\
\text { bonds }\end{array}$ & $\begin{array}{c}8 \% \\
\text { equities }\end{array}$ & all \\
\hline \multicolumn{12}{|c|}{ Country A - more skewed distribution of assets, more financial assets that react to monetary policy } \\
\hline share in total assets & & & 0.25 & 0.34 & 0.30 & 0.11 & & & & & \\
\hline size (units) & 100 & 600 & 150 & 204 & 180 & 66 & 500 & 0.6 & 2.4 & 2.9 & 5.9 \\
\hline mean-to-median & 1.3 & 6.5 & 2.1 & 152.4 & 40.0 & 4.2 & 28.4 & -6.9 & 2.0 & 0.8 & -4.2 \\
\hline Q5/Q3 & 3.1 & 28.6 & 7.0 & 755.3 & 193.6 & 17.0 & 137.2 & -7.1 & 2.0 & 0.8 & -4.3 \\
\hline Q5/Q1 & 5.2 & 152.2 & 30.8 & 5088.8 & 968.0 & 3473.4 & -87.4 & 1.6 & 2.6 & 3.2 & 7.4 \\
\hline \multicolumn{12}{|c|}{ Country B - less skewed distribution of assets, less financial assets that react to monetary policy } \\
\hline share in total assets & & & 0.50 & 0.25 & 0.08 & 0.17 & & & & & \\
\hline size (units) & 100 & 600 & 300 & 150 & 48 & 102 & 500 & 1.2 & 1.8 & 0.8 & 3.8 \\
\hline mean-to-median & 1.3 & 2.3 & 1.6 & 4.2 & 4.0 & 4.2 & 2.7 & -0.8 & 0.7 & 0.3 & 0.1 \\
\hline Q5/Q3 & 3.1 & 7.9 & 4.5 & 17.0 & 16.4 & 17.0 & 9.8 & -1.1 & 0.8 & 0.3 & 0.1 \\
\hline Q5/Q1 & 5.2 & 79.7 & 35.6 & 3473.4 & 128.0 & 3473.4 & -98.0 & 3.6 & 2.0 & 1.5 & 7.3 \\
\hline
\end{tabular}

Note: The higher the mean-to-median (M2M), $5^{\text {th }}$ quantile to $3^{\text {rd }}$ quantile $(\mathrm{Q} 5 / \mathrm{Q} 3)$ and $5^{\text {th }}$ quantile to $1^{\text {st }}$ quantile (Q5/Q1) ratios, the more unequal is the distribution. Thus, the positive changes in these ratios imply increased inequality and vice versa. The characteristics of country A are based on those of the United States and of country B on those of the euro area.

Source: Authors' calculations. 
Net wealth distribution effects stemming from policy-induced asset price changes depend also on how prices of particular assets are affected and on the structure of asset portfolios. Monetary policy is likely to have a differentiated impact on different asset prices and household asset portfolios vary across countries. To illustrate the role of these characteristics, stylised calculations for four asset classes have been undertaken (Table 4). It is assumed that, as a result of monetary policy easing, equity prices increase by $8 \%$, bond prices by $6 \%$ and real estate prices by $2 \%$, while prices of remaining assets do not change. ${ }^{16}$ Two stylised countries are presented. In country A, financial assets that react to monetary policy dominate and distributions of all assets are highly skewed. In country B, assets whose prices do not react to monetary policy or react only weakly dominate, and asset distributions are less skewed than in country A.

In country A, asset price increases reduce net wealth inequality, while they increase it in country B (Table 4). This reflects complex interactions of relative and absolute skewness of asset distributions and their sizes. In country A, households in the middle of the net wealth distribution gain a lot from the combined asset price increase, while this is not the case in country B. These results highlight that it is very difficult to know a priori what is the impact on net wealth distribution when asset portfolios, asset distributions and relative price changes differ. Thus, the assessment of the impact remains an empirical question.

As suggested by Boxes 1 and 4, in reality, asset price changes are unlikely to have a large effect on net wealth inequality. While bottom decile households see a large percentage increase in the value of their net wealth, this is compared with a very low base, so the overall effect on net wealth shares is small. Also, asset price gains that increase inequality (such as for equities) are likely to be offset by those that increase wealth for middle deciles (such as house price increases). Thus, even if monetary policy were to change asset valuations by as much as the valuation changes during the Great Recession, it would not alter the net wealth distribution significantly (Box 1).

\section{Income and wealth inequality and monetary policy transmission}

Households are an important channel for the transmission of monetary policy, with final household consumption accounting for around two-thirds of GDP in the main advanced economies. Monetary policy easing can induce households to consume more through income, wealth and credit-access effects. High wealth and income inequality could potentially reduce these effects. With higher inequality, monetary policy is directly transmitted mainly through households with large asset holdings and high incomes, and thus not liquidity constrained, and with a relatively low marginal propensity to consume (MPC). This section argues, however, that changes in the distribution of wealth and income of a magnitude similar to what has been experienced in recent decades are unlikely to have large effects on monetary policy transmission.

\subsection{Income inequality affects monetary policy transmission to consumption only marginally}

Cuts to interest rates have a priori ambiguous effects on income and consumption. The net income effect depends on the relative size of debt and interest-paying assets with varying interest rates (Section 3.2) but also on the MPC of borrowers and lenders.

- The relative importance of debt versus interest-paying assets varies greatly from country to country, but on average in the OECD almost twice as much debt is held as interest-paying assets,

16. The calibration of asset price changes broadly reflects the effects of a 100-basis point reduction in policy interest rates based on estimated elasticities mentioned in footnote 5 . 
even if total household assets exceed on average household debt (Section 4.4). Consequently, interest rate cuts are expected to increase overall income and consumption.

- Borrowers, especially with high debt servicing costs and large loans, usually have a larger MPC than lenders. ${ }^{17}$ If this is the case, total consumption can increase even if the income loss of lenders is equal or slightly larger than the income gain of borrowers.

Empirical evidence suggests both positive (in Japan) and negative consumption effects (in the United Kingdom and the United States) from interest rate increases (Aron et al., 2012).

The nexus of high inequality of income, debt and assets can, however, reduce the importance of the income effect. As high-income households hold the most debt, ${ }^{18}$ the income effect is concentrated among households that have a low MPC (Box 1; Table A2 in Annex). There is strong evidence which shows higher income groups have a lower MPC, such as di Maggio et al. (2015) finding that low-income US households and those with high loan-to-value ratios are more likely to increase consumption following an interest rate cut rather than pay back debt. Total interest-paying assets are generally more concentrated than debt. The exception is bank deposit accounts, which are a relatively widely held, but most households invest only small amounts in such accounts. Consequently, from a purely income effect perspective, with a more equal asset distribution, lower returns on assets would have a stronger negative impact on consumption.

Simulations in Box 2 show that changes in consumption stemming from policy-induced income effects (confined to interest-paying assets and debt servicing costs) are very small. Thus, more income and net wealth equality is unlikely to affect monetary policy transmission materially.

\subsection{The extent of wealth inequality does not affect the effectiveness of monetary policy either}

Net wealth inequality interacts with monetary policy transmission via changes in asset values. The increase in asset prices induced by monetary policy may prompt households to consume more, especially if such increases are perceived as permanent. It also pushes out the budget constraint of households. The wealth effect depends on the overall size of assets (and liabilities) and the nature of assets, such as housing versus financial assets (Sections 3.2 and 4.4), and the MPC. Empirical evidence suggests that aggregate wealth effects are economically important, but there is large uncertainty about exact estimates, which tend to vary across countries and asset classes (Box 3). Similarly, estimates of MPC by wealth deciles are uncertain.

17. Aladangady (2015) finds that, in the United States, those with debt service ratios in the highest quartile (and so likely to be credit constrained) have an MPC of 0.22 , compared with a statistically insignificant MPC for those with low debt service ratios. Mian et al. (2013) find that US zip-code areas with a large average loan-to-value (LTV) ratio $(90 \%)$ also have a MPC three times that of areas with an average LTV ratio of under $30 \%$.

18. There is a direct causal link between income and debt. Banks are hesitant to lend to low income households as they view them as higher-risk customers, partially due to lower collateral. High debt service ratios are an important factor in a household being denied credit (Johnson and Li, 2010). Banks are found to either discriminate using the interest rate they charge or by rationing debt, using a household's position in the income distribution as a signal of creditworthiness (Coibion et al., 2014). Greater income inequality increases the precision of this signal. 


\section{Box 3. Aggregate wealth effects on consumption}

Estimates of the average marginal propensity to consume (MPC) from wealth are typically in the region of 0.04 , and vary according to the type of asset and a country's regulatory environment (Aoki et al., 2004; Aron et al., 2012). The MPC from financial wealth is similar in the United States, Japan and the euro area (about 0.05 to 0.06 ), though the MPC from housing wealth is far higher in the United States (0.05) than in Japan and the euro area (0.01 to 0.015) (Poterba, 2000; Gourinchas and Parker, 2002; and Kerdrain, 2011). Consequently, the overall MPC from total wealth is higher in the United States than the two other economic areas. This may be due to more developed financial markets in the United States, which make it easier for households to use their home as collateral.

Although the MPC out of certain asset classes may be relatively large, small holdings of such assets will reduce their impact on the total economy. Despite the consistent and significant finding that the MPC from financial wealth is larger than for housing wealth, Case et al. (2005) find that, outside the United States, changes in financial asset prices have a weaker effect on aggregate consumption than changes in house prices. This may be due to relatively small holdings of financial assets in these countries. Also, households may view wealth increases due to monetary policy as transitory, reducing their impact on consumption. Using a VAR model, Ludvigson et al. (2002) find little evidence of an important wealth channel from monetary policy in the United States.

The wealth effect on consumption stemming from stock price movements seem to be stronger when prices are declining (Shirvani and Wilbratte, 2000; Apergis and Miller, 2006; and Ravn, 2014). This may reflect an inherent asymmetry in household preferences, where the utility loss from bad outcomes is larger than the utility gain from good outcomes (so called prospect theory; Kahneman and Tversky, 1979).

Wealth effects also depend on the distribution of assets, as the MPC out of wealth declines as wealth increases (Box 4; Table A3 in Annex). Thus, highly unequal wealth distribution lowers the effectiveness of monetary policy. Stylised simulations in Box 4 show that this is the case, but overall wealth inequality has only a small impact on the transmission of monetary policy.

There are two caveats that weaken wealth effects.

- Although asset price increases may boost aggregate consumption, they may reduce it for some groups. Increasing house prices can potentially reduce consumption by forcing younger people to save more. As housing wealth follows a consistent pattern over the life cycle (Figure 5), a country with a younger population may have a less positive housing wealth effect than a country with an older population.

- If wealth effects operate mainly via liquidating assets, in contrast to reduced saving, and via assets that tend to be more broadly held, such as housing and pension funds, then they may be reduced by institutional setting and regulations. House price increases may have a weaker wealth effect as, in contrast to financial wealth, liquidating housing assets can result in a drop in the quality of life due to a lack of shelter (Benito et al., 2006). The effect of changes in household wealth managed by institutions, such as pension funds, on household behaviour depends on the regulatory environment, which may prohibit households from drawing down wealth prior to retirement. 


\section{Box 4. How does inequality affect the transmission of monetary policy through the wealth channel?}

When the marginal propensity to consume (MPC) decreases with wealth and wealth is concentrated amongst those with a lower MPC, the transmission of monetary policy through wealth effects may be weakened. This box examines the importance of such effects and finds that they are small.

The role of inequality is examined by comparing changes in consumption stemming from changes in net wealth due to a general asset price increase under actual and counterfactual net wealth distributions. A more equal counterfactual wealth distribution assumes that $10 \%$ of the net wealth of the top decile is redistributed to other deciles. ${ }^{1}$ For the United States, this would imply reversing the increase in net wealth inequality from 1989 to 2013 . Net wealth distributions are based on the latest available microdata from household wealth surveys (Box 1). Prices of stocks, bonds, managed funds, real estate, and private businesses are assumed to increase by $10 \%$, with no change in the value of bank deposits, other assets that are unlikely to be affected by monetary policy (such as vehicles) and liabilities. $^{2}$

The impact of the net wealth increase on consumption is calculated using marginal MPC by net wealth deciles estimated by Carroll et al. (2014a, 2014b) (Table A3 in Annex; Box 2). Although the MPC is likely to vary depending on which asset increases in value (Box 3), it is assumed that it is the same for all asset types as estimates of the MPC broken down by both asset classes and deciles are unavailable. As consumption data are unavailable from the surveys used, percentage increases are calculated by dividing the simulated aggregate consumption increase by aggregate consumption taken from national accounts for the same year as the survey. Net wealth in national accounts is up to $40 \%$ higher than from the surveys for the euro area countries but $25 \%$ lower for Canada, $20 \%$ lower in the United Kingdom and $10 \%$ lower for the United States. This suggests that simulated consumption effects may be moderately underestimated for the euro area and overestimated for Canada, the United Kingdom and the United States.

The wealth distribution has a small impact on how asset price increases are transmitted to consumption (table below). Even if the assumed asset price increase boosts consumption by between $3.6 \%$ and $6.2 \%$ in the baseline, the changes induced by the shift in wealth distribution is marginal. With the more equal counterfactual net wealth distribution, consumption growth rates are the same or at most are higher by 0.2 percentage point than with the actual net wealth distribution. The cross-country differences reflect diversified levels of net wealth in relation to income, MPC and the composition of net wealth. For the euro area countries, these effects seem to be larger than implied by estimates based on aggregate data (Box 3).

The top decile gains a disproportionate share of the increase in consumption, and this may be of concern to policy makers. An unequal exposure to asset price increases is partially mitigated by a relatively higher MPC for poorer households, but the distribution of wealth dominates.

\section{Consumption effects of a $10 \%$ increase in asset values}

\begin{tabular}{|c|c|c|c|c|c|c|c|c|}
\hline & Belgium & Canada & France & Germany & Italy & $\begin{array}{l}\text { Nether- } \\
\text { lands }\end{array}$ & $\begin{array}{l}\text { United } \\
\text { Kingdom }\end{array}$ & $\begin{array}{l}\text { United } \\
\text { States }\end{array}$ \\
\hline Percentage increase in consumption: actual & 5.3 & 5.5 & 3.7 & 3.6 & 4.4 & 4.2 & 6.1 & $\overline{4.1}$ \\
\hline Percentage increase in consumption: counterfactual & 5.3 & 5.6 & 3.8 & 3.8 & 4.5 & 4.2 & 6.2 & 4.3 \\
\hline Difference: actual - counterfactual & -0.1 & -0.1 & -0.1 & -0.2 & -0.1 & 0.0 & -0.1 & -0.2 \\
\hline \multicolumn{9}{|l|}{ Memorandum } \\
\hline Share of consumption increase going to top $10 \%$ : actual & 37.7 & 41.0 & 46.5 & 52.5 & 39.2 & 25.5 & 36.7 & 61.8 \\
\hline Share of consumption increase going to top $10 \%$ : counterfactual & 33.6 & 36.3 & 41.0 & 44.8 & 34.6 & 22.8 & 32.6 & 52.7 \\
\hline Aggregate MPC & 0.066 & 0.065 & 0.064 & 0.068 & 0.069 & 0.073 & 0.067 & 0.067 \\
\hline Ratio of net wealth to consumption & 8.6 & 8.2 & 6.0 & 5.6 & 6.7 & 4.4 & 9.8 & 5.8 \\
\hline
\end{tabular}

Source: Authors' calculations.

1. A quarter of the $10 \%$ going equally to the bottom 5 deciles, a half to the 6 th, 7 th and 8 th decile, and a quarter to the 9 th decile.

2. For the United Kingdom, private businesses are not included. 
Figure 5. Mean housing wealth is lower for younger households'

Wealth holdings normalised relative to those of the 50-64 age group
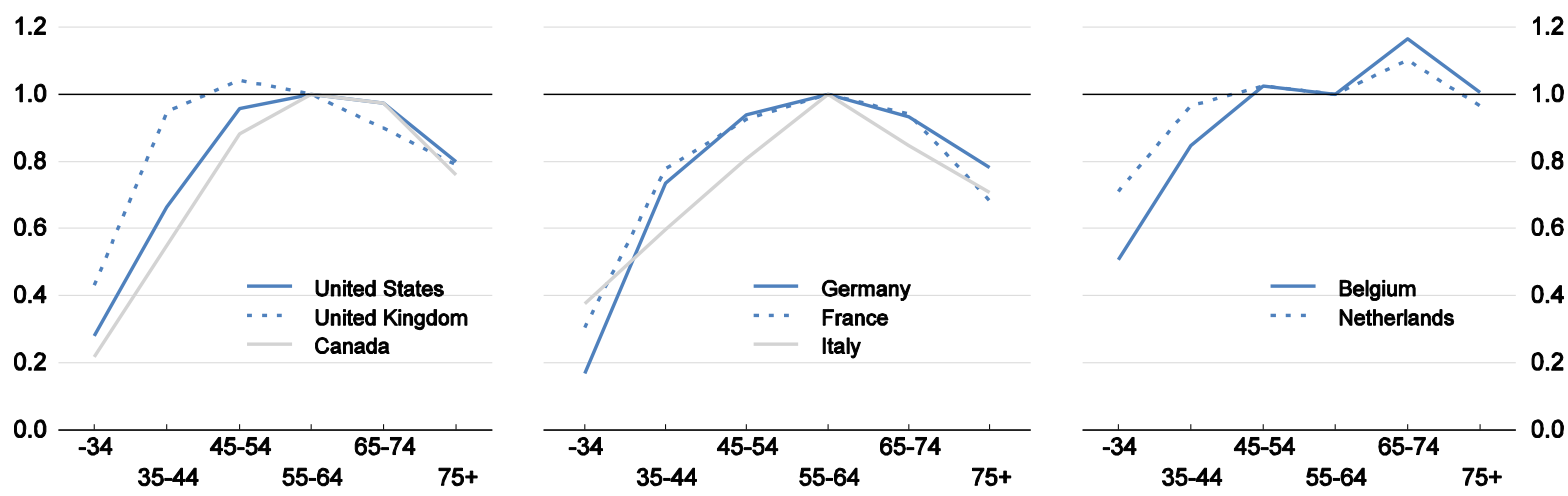

1. Data on net housing wealth refers to data on housing wealth net of liabilities.

Source: OECD Wealth Distribution Database.

\subsection{Inequality is unlikely to significantly reduce monetary policy effectiveness by strengthening credit constraints}

Cuts to interest rates through reduced policy rates and quantitative easing may induce households to shift future consumption to the present by borrowing or reducing savings. This channel of monetary policy transmission may be affected by an unequal distribution of income. Low-income households may have a lower elasticity of inter-temporal substitution (EIS), due to the fact that they consume proportionately more necessities than luxury goods and to a higher credit risk, due to lower income and higher chances of becoming unemployed, and thus more binding credit constraints. Indeed, Denk and Cazenave-Lacroutz (2015) show that low-income households in the euro area are more likely to be credit constrained than higher-income households. A more equal income distribution would likely imply a higher EIS at the bottom of income distribution and in turn more effective monetary policy. In spite of this theoretical justification, the direct empirical evidence on the link between income inequality and the EIS is mixed. ${ }^{19}$

Monetary policy could also ease access to, and reduce the cost of, credit by boosting asset values and thus improving household wealth and collateral (Bernanke and Gertler, 1995). This collateral channel crucially depends on whether the use of assets as collateral is allowed. Historically, mortgage equity withdrawals were generally more common in English-speaking countries than in continental European economies and Japan. Obtaining robust empirical evidence on the ensuing consumption effects is, however, complicated due to problems with distinguishing between collateral and direct wealth effects. However, there is some supporting evidence. ${ }^{20}$ For instance, US households with low credit scores and

19. In a meta-analysis, Havranek et al. (2015) find that countries with higher average income have a higher EIS. However, estimated structural models, where risk aversion and the EIS are inseparable, show that the EIS is lower (and risk aversion higher) for those with a higher education and occupational status, which correlate positively with higher income (Gourinchas and Parker, 2002; and Cagetti, 2003). However, the estimated lower risk aversion of low-income households may be due to their access to social insurance rather than underlying preferences. Attanasio and Browning (1995) find the EIS increases with the level of consumption, though consumption is more equally distributed than income (Heathcote et al., 2010).

20. Aoki et al. (2004) argue that house price increases have an effect through their use as collateral rather than an aggregate wealth effect as they represent redistribution rather than increase in wealth. Ciccarelli et al. (2014) also find that the collateral channel is relevant for the transmission of monetary policy to mortgages, however, in the United States and the euro area, changes in the cost of capital is the strongest channel. 
high credit card utilisation rates are most likely to borrow against an increase in home equity (Mian and Sufi, 2011). Following the financial crisis, indebted British households cut their spending more than nonindebted households, due to tighter credit conditions and concerns about the ability to make debt repayments (Bunn and Rostom, 2014). In France, highly indebted households are more sensitive to financial wealth increases, with the exception of those at the bottom of the distribution, who prefer to pay down debt (Arrondel et al., 2015).

Housing is the asset most used as collateral (Aoki et al., 2004) and its equal distribution, compared with other asset classes (Section 4.4), makes the collateral channel more relevant. ${ }^{21}$ This is not the case for assets used as collateral but mainly held by wealthy households that are not credit constrained. This is consistent with evidence that the EIS increases with wealth (Guvenen, 2006).

Monetary policy changes may not alter credit constraints significantly over the business cycle. As monetary policy tightening is only partially effective in limiting house price increases in booms, it may not trigger much tighter credit constraints. Similarly, during downturns, monetary policy actions that moderate house price declines that may alleviate the collateral constraints only moderately. The collateral channel may be particularly ineffective in the aftermath of a financial crisis due to the combination of several factors. Banks' capital and income positions limit credit expansion, irrespective of household balance sheets. Household credit risk increases (due to lower income and higher unemployment risk), notwithstanding collateral value gains. Households may also prefer to reduce indebtedness and not to take new credit. Moreover, monetary policy may not be able to offset large crisis-induced asset price declines.

\subsection{Cross-country differences in monetary policy effectiveness due to different size, structure and distribution of net wealth}

The size, composition and distribution of household financial assets differ across OECD economies, with implications for relative effectiveness of various monetary policy transmission channels across countries. A summary is given in Table 5 .

- Income effects from monetary policy easing are stronger in countries where the amount of debt is greater than interest-paying assets. According to wealth surveys, this is the case in all analysed countries apart from Belgium, whereas national accounts indicate that this not the case in Italy, Japan and the United States (Figure 6) ${ }^{22}$ Households in Canada, the Netherlands, the United Kingdom and the United States have relatively large debt-to-income ratios (especially for the bottom deciles), boosting the income effects from monetary easing. However, the effect of lower debt interest payments is countered in Belgium as interest-paying assets are larger, especially for lower income deciles (which have a higher MPC). Variable rate mortgages predominate in Italy and the Netherlands (Table 6), and account for roughly half of mortgages in Japan (Ministry of Land, Infrastructure, Transport and Tourism, 2015). In other countries in Table 6 and Canada (Bank of Canada, 2015) fixed rate mortgages dominate. In the United States, they tend to be pre-payable though, allowing borrowers to take advantage of lower rates by refinancing (Fuster and Vickery, 2014).

21. As a share of assets, the main residence tends to be of the greatest importance for the middle wealth deciles.

22. Household wealth surveys tend to underreport financial assets compared with the national accounts data, partially as the latter includes non-profit organisations serving households (Box 1.2 in ECB (2013)). 
Table 5. The impact of the size, composition and distribution of net wealth on monetary policy effectiveness

\begin{tabular}{|c|c|c|c|c|c|c|c|c|}
\hline & Belgium & Canada & France & Germany & Italy & $\begin{array}{c}\text { Nether- } \\
\text { lands }\end{array}$ & $\begin{array}{c}\text { United } \\
\text { Kingdom }\end{array}$ & $\begin{array}{l}\text { United } \\
\text { States }\end{array}$ \\
\hline \multicolumn{9}{|l|}{ Income effects (of assets and liabilities) } \\
\hline overall size (of assets plus liabilities) & + & + & - & + & - & ++ & + & + \\
\hline composition & -- & + & + & - & - & + & + & + \\
\hline distribution & + & + & + & + & + & + & + & - \\
\hline \multicolumn{9}{|l|}{ Wealth effects (of assets and liabilities) } \\
\hline overall size (of assets plus liabilities) & ++ & + & + & - & ++ & + & + & + \\
\hline composition & + & - & + & - & + & - & - & + \\
\hline distribution & + & + & + & - & + & + & + & - \\
\hline
\end{tabular}

Source: Authors' compilation.

Table 6. Large cross-country variation in shares of variable-rate mortgages

Per cent

\begin{tabular}{lrrrrrrrr} 
& & & & \multicolumn{2}{c}{ Per cent } & Euro & $\begin{array}{c}\text { United } \\
\text { Kingdom }\end{array}$ & $\begin{array}{c}\text { United } \\
\text { States }\end{array}$ \\
\hline Fixed rate & 62.2 & 80.8 & 84.9 & 35.5 & 14.8 & 50.1 & 73.8 & 88.3 \\
Variable rate & 35.2 & 17.6 & 14.2 & 46.3 & 76.5 & 43.9 & 26.2 & 12.6 \\
Unknown & 2.6 & 1.6 & 0.9 & 18.2 & 8.7 & 6.0 & & \\
\hline
\end{tabular}

Note: Data for the United States refer to residential mortgages only. The US total is greater than 100 due to the inclusion of mortgages on residences which include adjoining farmland. UK figures refer to the number, rather than stock, of mortgages. Data for Canada are not available.

Source: European Central Bank Household Finance and Consumption Survey; UK Wealth and Assets Survey by the Office for National Statistics; US Federal Reserve Survey of Consumer Finances; and authors' calculations.

Figure 6. Differences in debt and interest-paying assets

Per cent of income

\section{A. Wealth surveys (1)}
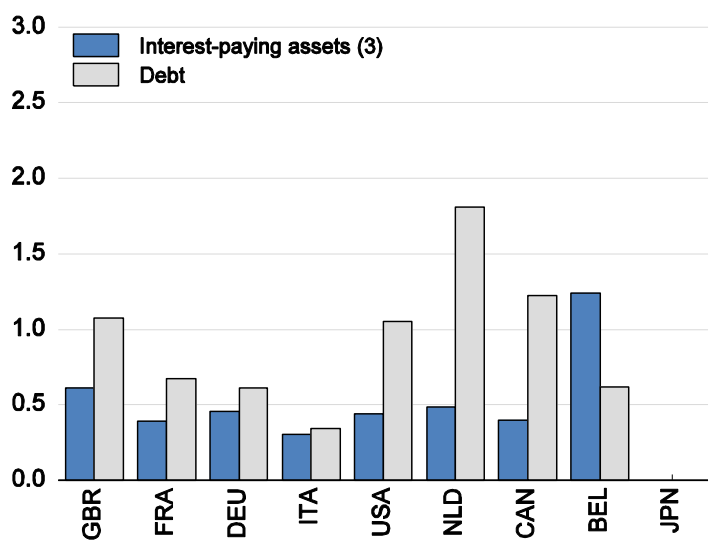

\section{B. National accounts (2)}

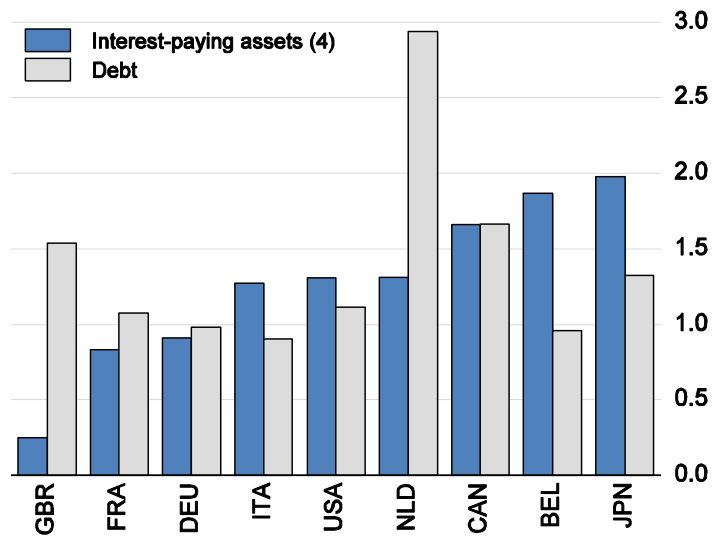

1. Per cent of gross income, including social transfers.

2. Per cent of disposable income. Including non-profit organisations serving households.

3. For Canada, deposits, savings accounts, and bonds. For euro area countries, savings accounts (excluding sight accounts), bonds, and mutual funds invested mainly in bonds and money markets. For the United Kingdom, savings accounts, national savings products, bonds, and cash and investment savings accounts. For the United States, call and savings accounts (excluding checking accounts), bonds, and mutual funds invested in bonds.

4. Fixed-income securities, loans, deposits other than transferable and a half of investment fund shares. For Canada, also currency and total deposits as data for deposits other than transferable are not available.

Source: Statistics Canada Survey of Financial Security (2012); European Central Bank Household Finance and Consumption Survey (2010); the UK Wealth and Assets Survey (2010-2012) by the Office for National Statistics; US Federal Reserve Survey of Consumer Finances (2013); OECD National Accounts database; OECD Economic Outlook 98 database; and authors' calculations. 
- Wealth effects induced by monetary easing are larger where assets whose prices are responsive to monetary policy (such as equities, bonds and real estate) are large relative to income. The size of such assets varies from 3.7 times income in Germany to 8.5 times in the United Kingdom (Figure 7). There are, however, important differences between wealth surveys and national accounts in the size of such assets, especially for Canada and Italy (where they are higher in surveys), and in the Netherlands and the United States (where they are lower in surveys). Assets that are more equally held, such as real estate, will have a larger wealth effect. Real estate wealth is more evenly distributed in Belgium, Canada, the Netherlands and the United Kingdom, but even in these countries it is concentrated in top deciles amongst which the MPC is similar (Table A3 in Annex).

Figure 7. The size and composition of assets vary across advanced countries

\section{A. Wealth surveys, ratio to gross income}

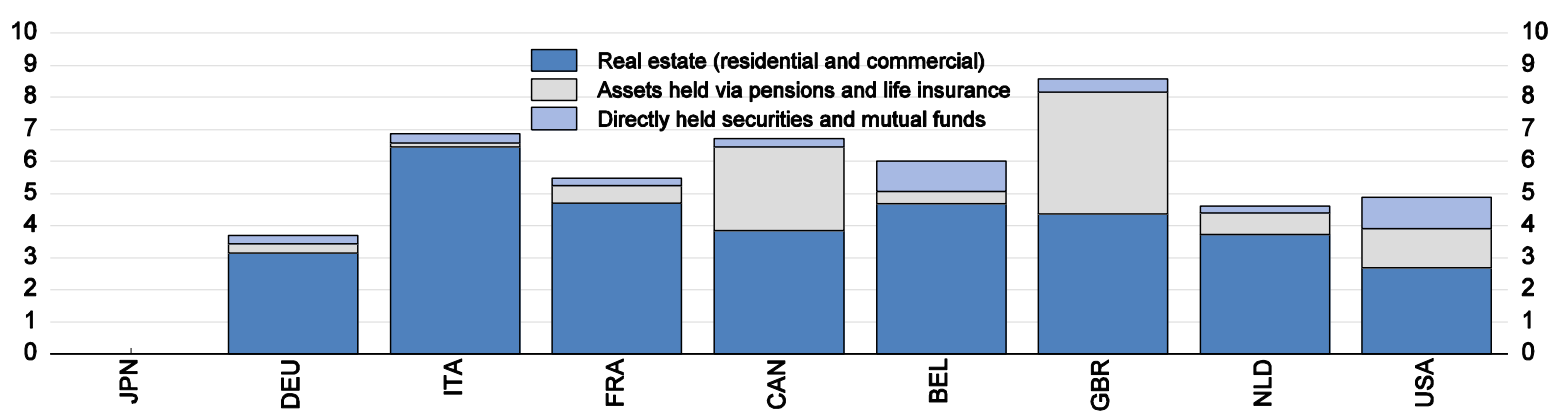

B. National accounts, ratio to disposable income

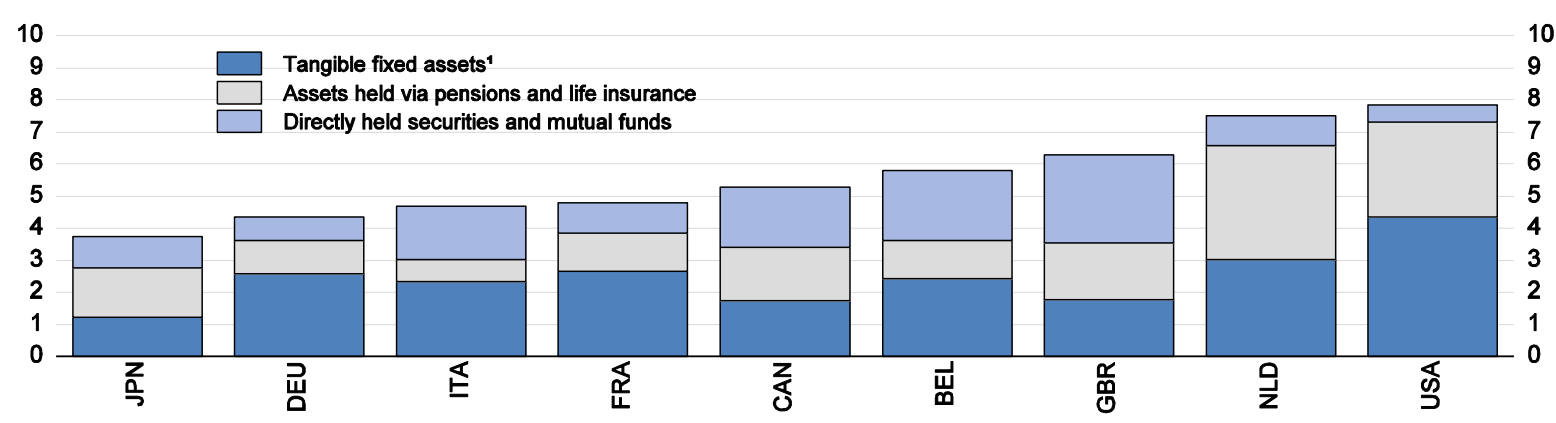

1. Includes dwellings; buildings other than dwellings; machinery and equipment and weapon system; and cultivated biological resources.

Source: Statistics Canada Survey of Financial Security (2012); European Central Bank Household Finance and Consumption Survey (2010); UK Wealth and Assets Survey (2010-2012) by the Office for National Statistics; US Federal Reserve Survey of Consumer Finances (2013); OECD National Accounts database; OECD Economic Outlook 98 database; and authors' calculations. 
Figure 8. The cumulative distribution of responsive assets does not vary much among lower deciles across countries
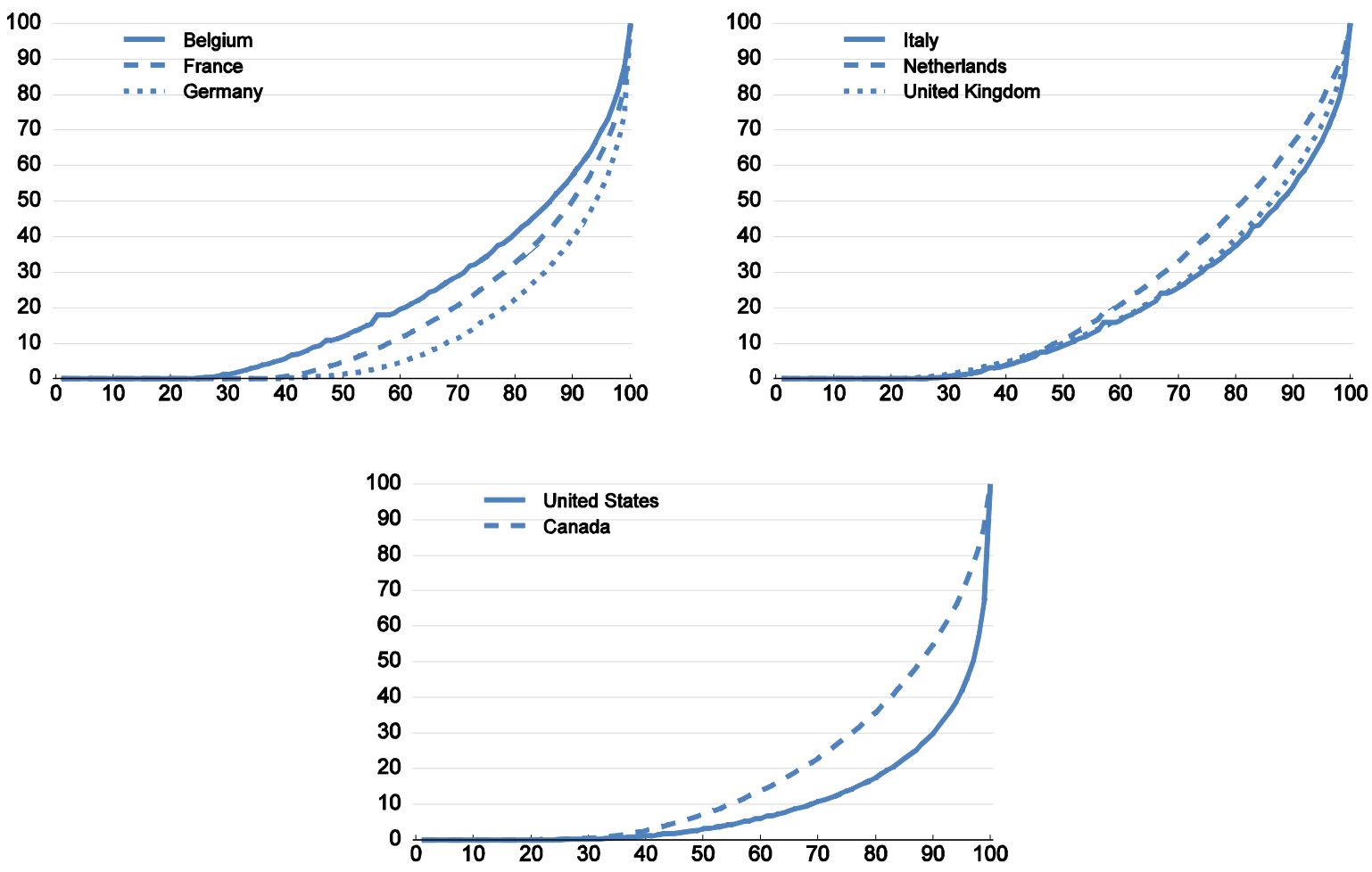

Note: The cumulative share of assets is also referred to as the Lorenz curve. Responsive assets are assets whose prices are assumed to react to monetary policy (as in Box 4). For Canada, these are retirement and pension funds, mutual funds, stocks, bonds, equity in business and real estate; for euro area countries, these are real estate, private-businesses (including of the self-employed), mutual funds, bonds, stocks, managed accounts and voluntary pension or whole life insurance; for the United Kingdom, these are stocks, pensions and insurance products, unit investment trusts, ISAs and real estate; for the United States, these are directly held pooled investment funds, stocks, bonds, cash value of whole life insurance, other managed assets, quasi-liquid retirement accounts, real-estate, and businesses with either an active or inactive interest.

Source: Statistics Canada Survey of Financial Security (2012); European Central Bank Household Finance and Consumption Survey (2010); UK Wealth and Assets Survey (2010-2012) by the Office for National Statistics; US Federal Reserve Survey of Consumer Finances (2013); and authors' calculations.

- $\quad$ Directly held securities, like stocks and bonds, and directly held mutual funds, are more liquid and thus more relevant for wealth effects. Thus, in the United States and Belgium, where they are high (relative to income), wealth effects induced by monetary policy are likely to be more potent than elsewhere (Figure 7). Wealth held via institutions is particularly important in Canada, the United Kingdom and the United States, but such assets tend to be less liquid. Directly held real estate tends to be less liquid, but plays an important role in Italy. Financial assets (both directly and indirectly held) are underreported in surveys compared with national accounts, while the opposite is true for real estate assets. The United States is an outlier both in terms of the total amount of financial wealth (relative to income), and in its concentration. The degree of leverage can magnify wealth effects of households. Low net wealth households in Canada, the Netherlands and the United States are particularly leveraged.

- Despite differences in the concentration of assets, cross country differences in wealth effects are likely to be driven by the aggregate size of assets (relative to income) rather than distribution. This is as most of the variance of wealth inequality across countries is within the top deciles, where the MPC does not vary by much, rather than between upper and lower deciles (Figure 8). 


\section{Policy implications}

Monetary policy has a limited direct impact on income and wealth inequality over the business cycle through changes in interest rates and asset prices. However, it reduces cyclical variation in inequality by stabilising the economy. In the longer term, if monetary authorities react symmetrically to declines and increases in equity prices, central banks do not contribute to increasing wealth inequality.

Even if inequality has a very limited negative impact on monetary policy transmission, rising inequality should be monitored because it risks contributing to financial crises through the "keeping-up with the Joneses" relative consumption effect. In this context, effective prudential regulation is needed to prevent too lax lending to risky household borrowers.

When interest rates are close to the zero lower bound, wealth inequality has a greater impact on the transmission channels of monetary policy than income inequality. This is because monetary policy can change asset prices to a larger extent than interest rates. The United States and the United Kingdom appear to have had stronger positive consumption effects stemming from wealth effects than appears likely in the euro area due to the distribution and nature of asset holdings in these areas. This may mean the success of the consumption channel of quantitative easing will not be repeated in the euro area. ${ }^{23}$

Interactions between monetary policy and inequality, even if very small, pose communication challenges. First, public concerns may arise due to the fact that increases in consumption resulting from monetary easing go mainly to the top net wealth deciles (Box 4), though the opposite is likely to be the case when interest rates increase. Second, even if cyclical implications of monetary policy for inequality as measured by the Gini coefficient are small, larger losses or gains for very specific and vocal groups tend to attract media attention. This calls for clear explanations of pros and cons of various inequality measures and all possible channels affecting the overall net effect; that current effects are likely to be reversed during the subsequent monetary policy tightening cycle; and that inequality fluctuations would be much larger without monetary policy intervention.

Because the impact of monetary policy on inequality through the asset and interest rate channels is weak and uncertain, monetary authorities, even if concerned about inequality, should focus on price stability and full employment. Correcting growing inequality by monetary policy instruments would require targeting asset prices, which is complicated due to difficulties with assessing equilibrium asset prices and could call for more frequent and larger interest rate changes. The latter could have potential negative consequence for consumer price and macroeconomic stability. Inequality is better addressed by fiscal and social policies, including progressive taxation and social welfare and equitable access to education (OECD, 2015).

23. This does not exclude a possibility though that monetary policy could be equally effective in boosting investment. Challenges with consumption channel may be also relevant for Japan, as the structure of Japanese financial assets suggests small wealth effects. According to national accounts, Japanese households hold a large share of their financial assets in the form of currency, deposits and net equity in life insurance and pensions funds. Consequently, assets that are responsive to policy changes and are directly held by households are very small in relation to income compared with other advanced countries. 


\section{REFERENCES}

Acemoglu, D. (2002), "Technical Change, Inequality, and the Labour Market", Journal of Economic Literature, Vol. 40/1, March, pp. 7-72.

Adam, K., and P. Tzamourani (2015), "Distributional consequences of asset price inflation in the euro area", Deutsche Bundesbank Discussion Paper, Vol. 2015/27.

Aladangady, A. (2015), "Household balance sheets and monetary policy", mimeo.

Albanesi, S. (2007), “Inflation and inequality”, Journal of Monetary Economics, Vol. 54/4, pp. 1088-1114.

Al-Marhubi, F. (1997), "A note on the link between income inequality and inflation”, Economics Letters, Vol. 55, September, pp. 317-319.

Aoki, K., J. Proudman, and G. Vlieghe (2002), "Houses as collateral: Has the link between house prices and consumption in the UK changed?", Federal Reserve Bank of New York Economic Policy Review, Vol. 8/1, pp. 163-178.

Aoki, K., J. Proudman, and G. Vlieghe (2004), "House prices, consumption, and monetary policy: A financial accelerator approach", Journal of Financial Intermediation, Vol. 13/4, pp. 414-435.

Apergis, N. and S. M. Miller (2006), "Consumption asymmetry and the stock market: Empirical evidence", Economics Letters, Vol. 93/3, pp. 337-342.

Aron, J., J. V. Duca, J. Muellbauer, K. Murata and A. Murphy (2012), "Credit, housing collateral and consumption: evidence from the UK, Japan and the US", Review of Income and Wealth, Vol. 58(3), pp. 397-423.

Arrondel, L., P. Lamarche and F. Savignac (2015), "Wealth effects on consumption across the wealth distribution: Empirical evidence", ECB Working Paper Series, No. 1817.

Attanasio, O. P. and M. Browning (1995), "Consumption over the Life Cycle and over the Business Cycle”, The American Economic Review, Vol. 85(5), pp. 1118-1137. DOI: 10.2307/2950978.

Atkinson, A. and S. Morelli (2011), "Economic Crises and Inequality," UNDP-HDRO Occasional Papers, No. $2011 / 6$.

Bank of Canada (2015), Financial System Review, June.

Benito, A., J. N. Thompson, M. Waldron and R. Wood (2006), "House prices and consumer spending", Bank of England Quarterly Bulletin, Summer.

Bernanke, B. S., and M. Gertler (1995), "Inside the black box: The credit channel of monetary policy transmission", The Journal of Economic Perspectives, Vol. 9/4, pp. 27-48.

Bernanke, B. S., and K. N. Kuttner (2005), "What explains the stock market's reaction to Federal Reserve policy?", The Journal of Finance, Vol. 60/3, pp. 1221-1257.

Bivens, J. (2015), "Gauging the impact of the Fed on inequality during the great recession", Hutchins Centre on Monetary Policy at Brookings Working Paper, Vol. 2015/12.

Bordo, M. D. and C. M. Meissner (2012), "Does inequality lead to a financial crisis?", Journal of International Money and Finance, Vol. 31/8, pp. 2147-2161. 
Bullard, J. (2014), "Income inequality and monetary policy: a framework with answers to three questions", speech at C. Peter McClough Series on International Economics, Council on Foreign Relations, June 24.

Bulír, A. and A. Gulde (1995), "Inflation and income distribution: further evidence on empirical links", IMF Working Papers, No. 86, International Monetary Fund.

Bulír, A. (2001), "The impact of macroeconomic policies on the distribution of income", Annals of Public and Cooperative Economics, Vol. 72/2, pp. 253-270.

Bunn, P. and M. Rostom (2014), "Household debt and spending", Bank of England Quarterly Bulletin, 2014/Q3.

Cagetti, M. (2003), "Wealth accumulation over the life cycle and precautionary savings", Journal of Business and Economic Statistics, Vol. 21/3, pp. 339-353.

Card, D. (2001), "The effect of unions on wage inequality in the U.S. labor market," Industrial and Labor Relations Review, Vol. 54(2), pp. 296-315.

Carpenter, S. B. and W M. Rodgers III (2004), "The disparate labor market impacts of monetary policy," Journal of Policy Analysis and Management, Vol. 23/4, pp. 813-830.

Carroll, C. D., J. Slacalek and K. Tokuoka (2014a), "The distribution of wealth and the MPC: Implications of new European data”, ECB Working Paper Series, No. 1648.

Carroll, C.D., J. Slacalek and K. Tokuoka (2014b), "The distribution of wealth and the marginal propensity to consume", ECB Working Paper Series, No. 1655.

Case, K. E., J. M. Quigley, and R.J. Shiller (2005), "Comparing wealth effects: The stock market versus the housing market", Advances in Macroeconomics, Vol. 5/1.

Casiraghi, M. E. Gaiotti, M.L. Rodano and A. Secchi (2016), "A reverse Robin Hood? The distributional implications of non-standard monetary policy for Italian households", Banca D'Italia Working Paper, forthcoming.

Ciccarelli, M., A. Maddaloni, and J.L. Peydró, (2014), "Trusting the bankers: A new look at the credit channel of monetary policy", Review of Economic Dynamics, article in press.

Coibion, O., Y. Gorodnichenko, L. Kueng, and J. Silvia (2012), "Innocent bystanders? Monetary policy and inequality in the U.S.", NBER Working Paper, No. 18170, National Bureau of Economic Research.

Coibion, O., Y. Gorodnichenko, M. Kudlyak, and J. Mondragon, (2014), "Does greater inequality lead to more household borrowing? New Evidence from Household Data", National Bureau of Economic Research Working Paper Series, No. 19850.

Coeuré, B. (2012), "What can monetary policy do about inequality?", speech at International Day for the Eradication of Poverty, Intergroup "Extreme Poverty and Human Rights, Fourth World Committee" event, European Parliament, Brussels, 17 October.

Cournède, B., O. Denk and P. Hoeller (2015), "Finance and inclusive growth," OECD Economic Policy Papers, No. 14, OECD Publishing, Paris. 
Denk, O. and A. Cazenave-Lacroutz (2015), "Household finance and income inequality in the euro area", OECD Economics Department Working Papers, No. 1226, OECD Publishing, Paris. http://dx.doi.org/10.1787/5js04v5wh9zs-en

Denk, O. and B. Cournède (2015), "Finance and income inequality in OECD countries", OECD Economics Department Working Papers, No. 1224, OECD Publishing, Paris.

DOI: http://dx.doi.org/10.1787/5js04v5jm2hl-en

di Maggio, M., A. Kermani, and R. Ramcharan (2015), "Monetary policy pass-through: Household consumption and voluntary deleveraging", mimeo.

Dobbs, R., S. Lund, T. Koller, and A. Shwayder (2013), "QE ultra-low interest rates: Distributional effects and risks", McKinsey Global Institute Discussion Paper, November 2013.

Doepke, M. and M. Schneider (2006), "Inflation and the redistribution of nominal wealth," Journal of Political Economy, Vol. 114/6, pp. 1069-1097.

Engen, E. M., T. Laubach and D. Reifschneider (2015), "The macroeconomic effects of the Federal Reserve's unconventional monetary policies”, FEDS Working Paper, No. 2015-005, Board of Governors of the Federal Reserve System Finance and Economics Discussion Series, January 14.

ECB (2013), "The Eurosystem Household Finance and Consumption Survey - Results from the first wave”, ECB Statistics Paper Series, No. 2, April, European Central Bank.

Feenstra, R. and G. Hanson (2004), "Global production sharing and rising inequality: A survey of trade and wages", Chapter 6 of Part I in K. M. Choi and J. Harrigan (eds), Handbook of International Trade.

Fuster, A. and J. Vickery (2014), "Securitization and the fixed-rate mortgage", Review of Financial Studies, online preprint, DOI: 10.1093/rfs/hhu060.

Galli, R. and R. van der Hoeven (2001), "Is inflation bad for income inequality: The importance of the initial rate of inflation", Employment Paper, No. 29, International Labour Office.

Gertler, M. and S. Glichrist (1994), "Monetary policy, business cycles and the behaviour of small manufacturing firms", The Quarterly Journal of Economics, Vol. 59/2, pp. 309-340.

Gourinchas, P.-O. and J. A. Parker (2002), "Consumption over the life cycle", Econometrica, Vol. 70/1, pp. $47-89$.

Guvenen, F. (2006), "Reconciling conflicting evidence on the elasticity of intertemporal substitution: A macroeconomic perspective", Journal of Monetary Economics, Vol. 53/7, pp. 1451-1472.

Havranek, T., R. Horvath, Z. Irsova and M. Rusnak (2015), "Cross-country heterogeneity in intertemporal substitution”, Journal of International Economics, Vol. 96/1, pp. 100-118.

Heathcote, J., F. Perri, and G. Violante (2010), "Unequal we stand: an empirical analysis of economic inequality in the U.S., 1967-2006", Review of Economic Dynamics, Vol. 13/1, pp. 15-51.

Heer, B. and B. Süssmuth (2003), "Cold progression and its effects on income distribution", CESifo Working Paper Series, No. 951. 
Huber, E. and J.D. Stephens (2014), "Income inequality and redistribution in post-industrial democracies: Demographic, economic and political determinants", Socio-Economic Review, Vo. 12(2), pp. 245267. DOI:10.1093/ser/mwu001.

Jaumotte, F. and C. Osorio Buitron (2015), "Inequality and labour market institutions", IMF Staff Discussion Note, No. 15/14.

Johnson, K. W., and G. Li (2010), "The debt-payment-to-income ratio as an indicator of borrowing constraints: Evidence from two household surveys", Journal of Money, Credit and Banking, Vol. 42/7, pp. 1373-1390.

Kahneman, D. and A. Tversky (1979), "Prospect theory: An analysis of decision under risk", Econometrica, Vol. 47(2), pp. 263-291.

Karahan, F. and S. Ozkan (2013), "On the persistence of income shocks over the life cycle: Evidence, theory, and implications", Review of Economic Dynamics, Vol. 16/3, pp. 452-476.

Karras, G. (1996), "Are the output effects of monetary policy asymmetric? Evidence from a sample of European countries", Oxford Bulletin of Economics and Statistics, Vol. 58/2, pp. 267-278.

Kerdrain, C. (2011), "How important is wealth for explaining household consumption over the recent crisis?: An empirical study for the United States, Japan and the Euro Area", OECD Economics Department Working Papers, No. 869, OECD Publishing. http://dx.doi.org/10.1787/5kgc42qxm237en

Kumhof, M., R. Rancière, and W. Pablo (2015), "Inequality, leverage, and crises", American Economic Review, Vol. 105/3, pp. 1217-1245.

Ludvigson, S., C. Steindel, and M. Lettau, (2002), "Monetary policy transmission through the consumption-wealth channel”, FRBNY Economic Policy Review, Vol. 5, pp. 117-133.

Martin, C. and C. Milas (2012), "Quantitative easing: A sceptical survey", Oxford Review of Economic Policy, Vol. 28/4, pp. 750-764.

Mian, A., and A. Sufi (2011), "House prices, home equity-based borrowing, and the US household leverage crisis", The American Economic Review, Vol. 101/5, pp. 2132-2156.

Mian, A., K. Rao, and A. Sufi (2013), "Household balance sheets, consumption, and the economic slump", The Quarterly Journal of Economics, Vol. 128/4, pp. 1687-1726.

Ministry of Land, Infrastructure, Transport and Tourism (2015), "Heisei 26-nendo minkan juutaku rôn no jittai ni kansuru chosa kekka houkoku sho" (A report of survey on private housing loans in fiscal year 2014), Housing Bureau, Ministry of Land, Infrastructure, Transport and Tourism, Japanese Government.

Morgan, D. P. (1993), "Asymmetric effects of monetary policy", Federal Reserve Bank of Kansas City Economic Review, $2^{\text {nd }}$ Quarter, Vol. 78, pp. 21-33.

Mulligan, C. and X. Sala-i-Martin (2000), "Extensive margins and the demand for money at low interest rates", Journal of Political Economy, Vol. 108/5, pp. 961-991.

Nakajima, M. (2015), “The redistributive consequences of monetary policy," Business Review, Second Quarter 2015, Federal Reserve Bank of Philadelphia Research Department. 
OECD (2015), In It Together: Why Less Inequality Benefits All, OECD Publishing, Paris. http://dx.doi.org/10.1787/9789264235120-en.

Panetta, F. (2015), "The distributional consequences of monetary policy", Remarks at the Netherlands Bank, Amsterdam, 20 November.

Parker, S. C. (1999), "Income inequality and the business cycle: A survey of the evidence and some new results", Journal of Post Keynesian Economics, Vol. 21/2, pp. 201-225.

Peek, J., E. S. Rosengren, and G.M.B. Tootell (2015), "Should U.S. monetary policy have a ternary mandate?", presentation in 59th Economic Conference, Federal Reserve Bank of Boston, October 2 2015, www.bostonfed.org/macroprudential2015/papers/Rosengren-Peek-Tootell.pdf.

Peersman, G., and F. Smets (2005), "The industry effects of monetary policy in the euro area", Economic Journal, Vol. 115, pp. 319-342.

Piketty, T. (2014), Capital in the Twenty-First Century, Harvard University Press.

Poterba, J. M. (2000), "Stock market wealth and consumption", The Journal of Economic Perspectives, $14 / 2$, pp. 99-118.

Rajan, R. (2010), Faulty Lines: Fault Lines: How Hidden Fractures Still Threaten the World Economy, Princeton University Press.

Ravn, S. H. (2012), "Has the Fed reacted asymmetrically to stock prices?", The B.E. Journal of Macroeconomics, Vol. 12/1, pp. 1-36.

Ravn, S. H. (2014), “Asymmetric monetary policy towards the stock market: A DSGE approach”, Journal of Macroeconomics, Vol. 39, Part A, March, pp. 24-41. http://dx.doi.org/10.1016/j.jmacro.2013.11.002.

Rigobon, R. and B. Sack (2004), "The impact of monetary policy on asset prices", Journal of Monetary Economics, Vol. 51/8, pp. 1553-1575.

Romer, C. D. and D. H. Romer (1999), "Monetary policy and the well-being of the poor", Economic Review, First Quarter, Federal Reserve Bank of Kansas City, pp. 21-49.

Saez, E. and G. Zucman (2014), "Wealth inequality in the united states since 1913: Evidence from capitalized income tax data", NBER Working Paper Series, No. 20625, October, DOI: $10.3386 / \mathrm{w} 20625$.

Shirvani, H. and B. Wilbratte (2000), "Does consumption respond more strongly to stock market declines than to increases?", International Economic Journal, Vol. 14 (3), pp. 41-49.

Smith, J. P. (2004), “Why is wealth inequality rising?”, EconWPA Macroeconomics, No. 0402012.

Tenreyro, S. and G. Thwaites (2013), "Pushing on a string: US monetary policy is less powerful in recessions", Centre for Macroeconomics Discussion Papers, No. 1301 (Revised version, January 2015).

van Treeck, T. (2014), "Did inequality cause the U.S. financial crisis?”, Journal of Economic Surveys, Vol. 28/3, pp. $421-448$.

Yellen, J. (2014), "Perspectives on inequality and opportunity from the survey of consumer finances", speech at the Conference on Economic Opportunity and Inequality, Federal Reserve Bank of Boston, Boston, Massachusetts, October 17. 


\section{ANNEX. SUPPORTING TABLES AND FIGURES}

Table A1. Households at the bottom of the net wealth distribution are more leveraged than those at the top Assets-to-liabilities ratio

\begin{tabular}{lrrrrrrrr} 
& Belgium & \multicolumn{1}{c}{ Canada } & France & Germany & \multicolumn{1}{l}{ Italy } & Netherlands & United Kingdom & United States \\
\hline 1st & 0.8 & 0.5 & 0.6 & 0.6 & 1.2 & 0.7 & 1.1 & 0.6 \\
2nd & 2.3 & 1.8 & 3.8 & 2.2 & 5.0 & 1.1 & 2.8 & 1.1 \\
3rd & 2.3 & 1.7 & 3.0 & 2.2 & 3.8 & 1.3 & 2.4 & 1.3 \\
4th & 2.8 & 1.8 & 2.5 & 3.8 & 6.1 & 1.6 & 3.0 & 1.4 \\
5th & 6.0 & 2.5 & 3.2 & 2.7 & 14.0 & 2.0 & 4.5 & 1.8 \\
6th & 7.8 & 3.4 & 5.3 & 3.1 & 23.8 & 2.4 & 5.6 & 2.4 \\
7th & 9.8 & 5.3 & 8.7 & 4.9 & 33.1 & 2.8 & 8.6 & 3.0 \\
8th & 19.6 & 7.3 & 12.7 & 7.5 & 28.8 & 4.2 & 9.3 & 4.2 \\
9th & 20.0 & 11.1 & 15.4 & 9.7 & 31.7 & 6.5 & 15.5 & 6.1 \\
10th & 53.6 & 19.1 & 21.9 & 18.8 & 48.3 & 7.3 & 24.5 & 17.5 \\
all & 12.1 & 7.0 & 10.4 & 8.4 & 24.4 & 3.0 & & 9.4 \\
\hline
\end{tabular}

Note: A ratio below 1 implies negative net wealth (i.e. higher liabilities than assets).

Source: ECB Household Finance and Consumption Survey; US Federal Reserve Survey of Consumer Finances; UK Wealth and Assets Survey (2010-2012) by the Office for National Statistics; Survey of Financial Security (2012) by Statistics Canada; and authors' calculations.

Table A2. Marginal propensity to consume by income deciles

\begin{tabular}{lrrrrrrr}
\multicolumn{1}{c}{ Decile } & Belgium & France & Germany & \multicolumn{1}{c}{ Italy } & Netherlands & Euro area & United States \\
\hline 1st & 0.10 & 0.14 & 0.24 & 0.15 & 0.11 & 0.12 & 0.22 \\
2nd & 0.10 & 0.14 & 0.24 & 0.15 & 0.11 & 0.12 & 0.22 \\
3rd & 0.10 & 0.14 & 0.24 & 0.15 & 0.11 & 0.12 & 0.22 \\
4th & 0.10 & 0.14 & 0.24 & 0.15 & 0.11 & 0.12 & 0.22 \\
5th & 0.11 & 0.13 & 0.19 & 0.12 & 0.12 & 0.12 & 0.20 \\
6th & 0.10 & 0.12 & 0.19 & 0.11 & 0.11 & 0.12 & 0.18 \\
7th & 0.10 & 0.12 & 0.18 & 0.11 & 0.11 & 0.11 & 0.19 \\
8th & 0.10 & 0.12 & 0.18 & 0.11 & 0.11 & 0.11 & 0.19 \\
9th & 0.08 & 0.10 & 0.16 & 0.09 & 0.09 & 0.10 & 0.17 \\
10th & 0.07 & 0.10 & 0.16 & 0.09 & 0.08 & 0.09 & 0.17 \\
\hline
\end{tabular}

Note: Euro area averages, as estimated by Carroll et al. (2014a), are used for Canadian and UK simulations.

Source: Carroll et al. (2014a), "The distribution of wealth and the MPC: Implications of new European data", ECB Working Paper Series, No. 1648; and Carroll et al. (2014b), "The distribution of wealth and the MPC: Implications of new European data", ECB Working Paper Series, No. 1655. 
ECO/WKP(2016)5

Table A3. Marginal propensity to consume by wealth deciles

\begin{tabular}{lrrrrrrr}
\multicolumn{1}{c}{ Decile } & Belgium & France & Germany & \multicolumn{1}{c}{ Italy } & Netherlands & Euro area & United States \\
\hline 1st & 0.14 & 0.19 & 0.34 & 0.19 & 0.16 & 0.17 & 0.32 \\
2nd & 0.14 & 0.19 & 0.34 & 0.19 & 0.16 & 0.17 & 0.32 \\
3rd & 0.14 & 0.19 & 0.34 & 0.19 & 0.16 & 0.17 & 0.32 \\
4th & 0.14 & 0.19 & 0.34 & 0.19 & 0.16 & 0.17 & 0.32 \\
5th & 0.07 & 0.07 & 0.09 & 0.07 & 0.07 & 0.07 & 0.09 \\
6th & 0.06 & 0.07 & 0.08 & 0.07 & 0.06 & 0.06 & 0.06 \\
7th & 0.06 & 0.06 & 0.07 & 0.07 & 0.06 & 0.06 & 0.06 \\
8th & 0.06 & 0.06 & 0.07 & 0.07 & 0.06 & 0.06 & 0.06 \\
9th & 0.06 & 0.06 & 0.06 & 0.06 & 0.06 & 0.06 & 0.06 \\
10th & 0.06 & 0.06 & 0.06 & 0.06 & 0.06 & 0.06 & 0.06 \\
\hline Not: & 0.06 & &
\end{tabular}

Note: Euro area averages, as estimated by Carroll et al. (2014a), are used for Canadian and UK simulations.

Source: Carroll et al. (2014a), "The distribution of wealth and the MPC: Implications of new European data", ECB Working Paper Series, No. 1648; and Carroll et al. (2014b), "The distribution of wealth and the MPC: Implications of new European data", ECB Working Paper Series, No. 1655.

Figure A1. Income sources differ across the income distribution

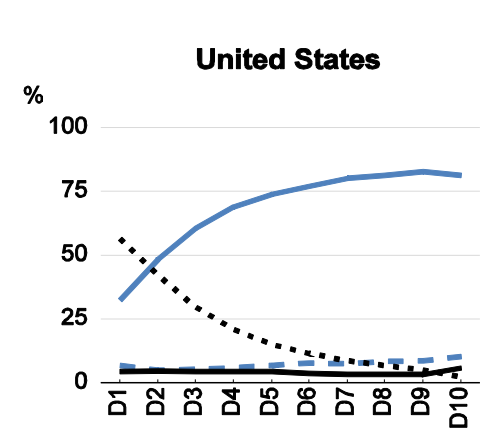

$\%$

$\%$

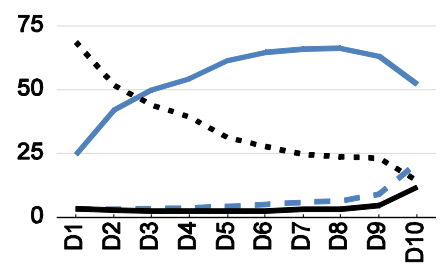

Shares in market income, in per cent
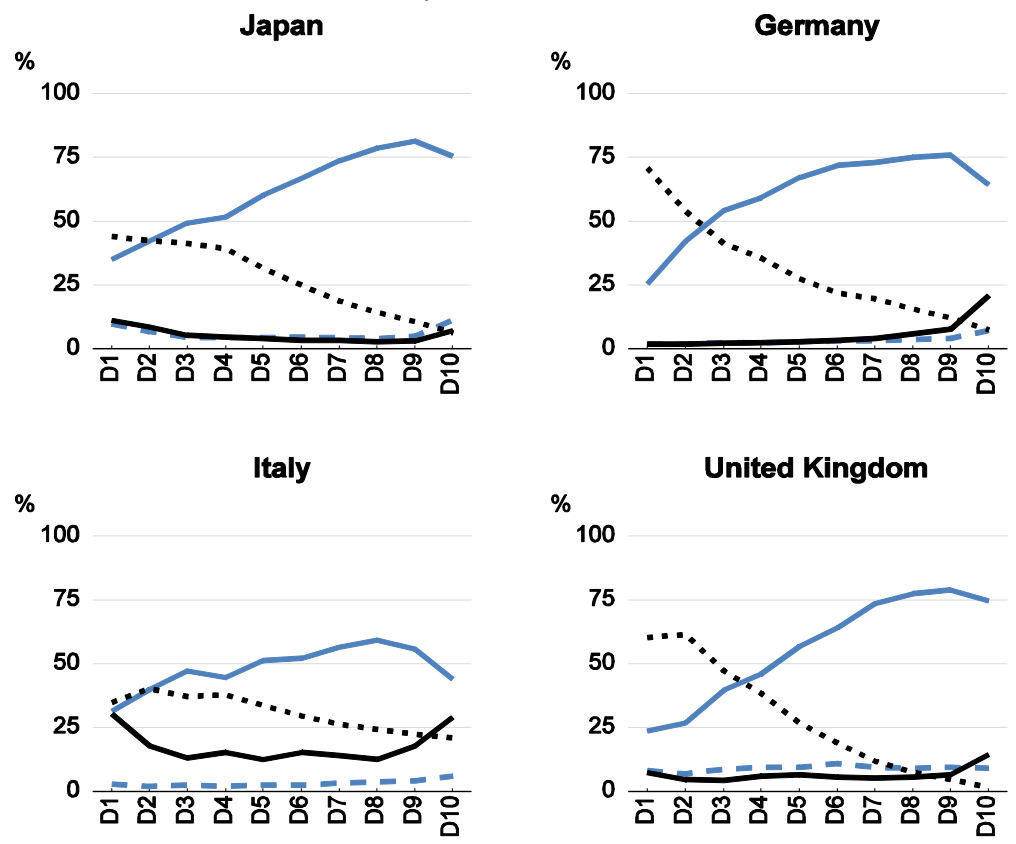

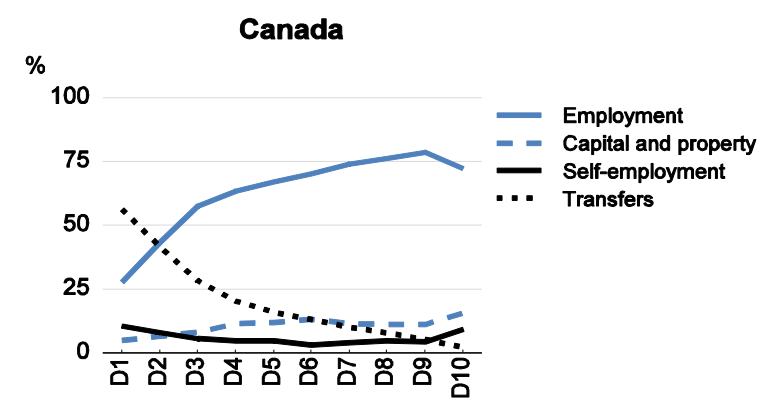

Source: OECD Income Inequality Database. 